\title{
Recent population expansion of longtail tuna Thunnus tonggol (Bleeker, 1851) inferred from the mitochondrial DNA markers
}

\author{
Noorhani Syahida Kasim ${ }^{1}$, Tun Nurul Aimi Mat Jaafar ${ }^{1}$, Rumeaida Mat Piah ${ }^{1}$, Wahidah Mohd Arshaad ${ }^{2}$, Mohd Nor \\ Siti Azizah $^{3}$, Ahasan Habib ${ }^{1,4}$, Abd. Ghaffar Mazlan ${ }^{3}$, Yeong Yik Sung ${ }^{3}$, Muhd Danish-Daniel ${ }^{1,3}$, Min Pau Tan ${ }^{\text {Corresp. }}$ \\ 1,3 \\ ${ }^{1}$ Faculty of Fisheries and Food Science, Universiti Malaysia Terengganu, Terengganu, Malaysia \\ 2 Marine Fishery Resources Development and Management Department (MFRDMD), Taman Perikanan, Chendering, Kuala Terengganu, Malaysia \\ 3 Institute Marine Biotechnology (IMB), Universiti Malaysia Terengganu, Terengganu, Malaysia \\ 4 Department of Fisheries and Marine Science, Noakhali Science and Technology University, Noakhali, Bangladesh
}

Corresponding Author: Min Pau Tan

Email address: mptan@umt.edu.my

The population genetic diversity and demographic history of the longtail tuna Thunnus tonggol in Malaysian waters was investigated using mitochondrial DNA (mtDNA) D-loop and NADH dehydrogenase subunit 5 (ND5). A total of 203 (D-loop) and 208 (ND5) individuals of $T$. tonggol were sampled from 11 localities around the Malaysian coastal waters. Low genetic differentiation between populations was found, possibly due to the past demographic history, dispersal potential during egg and larval stages, seasonal migration in adults, and lack of geographical barriers. The gene trees, constructed based on the maximum likelihood (ML) method, revealed a single panmictic population with unsupported internal clades, indicating an absence of structure among the populations studied. Analysis on population pairwise comparison $\Phi_{\mathrm{ST}}$ suggested the absence of limited gene flow among study sites. Taken all together, high haplotype diversity (Dloop $=0.989-1.000 ; N D 5=0.848-0.965)$, coupled with a low level of nucleotide diversity (Dloop $=0.019-0.025 ;$ ND5=0.0017-0.003), "star-like" haplotype network, and unimodal mismatch distribution, suggests a recent population expansion for populations of $T$. tonggol in Malaysia. Furthermore, neutrality and goodness of fit tests supported the signature of a relatively recent population expansion during the Pleistocene epoch. To provide additional insight into the phylogeographic pattern of the species within the IndoPacific Ocean, we included haplotypes from GenBank and a few samples from Taiwan. Preliminary analyses suggest a more complex genetic demarcation of the species than an explicit Indian Ocean versus Pacific Ocean delineation. 
1 Recent population expansion of longtail tuna Thunnus tonggol (Bleeker, 1851) inferred from the 2 mitochondrial DNA markers

3 Noorhani Syahida Kasim ${ }^{1}$, Tun Nurul Aimi Mat Jaafar ${ }^{1}$ Rumeaida Mat Piah ${ }^{1}$, Wahidah Mohd 4 Arshaad $^{2}$, Mohd Nor Siti Azizah ${ }^{3}$, Ahasan Habib ${ }^{1,4}$, Abd. Ghaffar Mazlan ${ }^{3}$, Yeong Yik Sung 3 , 5 Muhd Danish-Daniel ${ }^{1,3}$, and Min Pau Tan ${ }^{1,3 *}$

$9{ }^{2}$ Marine Fishery Resources Development and Management Department (MFRDMD), Taman

10 Perikanan, Chendering, 21080 Kuala Terengganu, Malaysia.

$11{ }^{3}$ Institute of Marine Biotechnology (IMB), Universiti Malaysia Terengganu, 21030 Kuala Nerus, 12 Terengganu, Malaysia.

${ }^{4}$ Department of Fisheries and Marine Science, Noakhali Science and Technology University, Noakhali-3814, Bangladesh.

Corresponding Author:

\section{Tan Min $\mathrm{Pau}^{1}$}

Faculty of Fisheries and Food Science, Universiti Malaysia Terengganu, 21030 Kuala Nerus, Terengganu, Malaysia.

Email address: mptan@umt.edu.my

\section{ABSTRACT}

The population genetic diversity and demographic history of the longtail tuna Thunnus tonggol in Malaysian waters was investigated using mitochondrial DNA (mtDNA) D-loop and NADH dehydrogenase subunit 5 (ND5). A total of 203 (D-loop) and 208 (ND5) individuals of T. tonggol were sampled from 11 localities around the Malaysian coastal waters. Low genetic differentiation between populations was found, possibly due to the past demographic history, dispersal potential during egg and larval stages, seasonal migration in adults, and lack of geographical barriers. The gene trees, constructed based on the maximum likelihood (ML) method, revealed a single panmictic population with unsupported internal clades, indicating an absence of structure among the populations studied. Analysis on population pairwise comparison $\Phi_{\mathrm{ST}}$ suggested the absence 
33 of limited gene flow among study sites. Taken all together, high haplotype diversity (D-

34 loop $=0.989-1.000$; ND5 $=0.848-0.965)$, coupled with a low level of nucleotide diversity (D-

35 loop $=0.019-0.025$; ND5=0.0017-0.003), "star-like" haplotype network, and unimodal mismatch

36 distribution, suggests a recent population expansion for populations of T. tonggol in Malaysia.

37 Furthermore, neutrality and goodness of fit tests supported the signature of a relatively recent

38 population expansion during the Pleistocene epoch. To provide additional insight into the

39 phylogeographic pattern of the species within the Indo-Pacific Ocean, we included haplotypes

40 from GenBank and a few samples from Taiwan. Preliminary analyses suggest a more complex

41 genetic demarcation of the species than an explicit Indian Ocean versus Pacific Ocean delineation.

42 Subject: Molecular Ecology, Genetics, Fisheries

43 Keywords: Genetic diversity, population expansion, longtail tuna Thunnus tonggol, 
INTRODUCTION

Thunnus tonggol, locally known as aya/ tongkol hitam or longtail tuna, is a pelagic-neritic marine fish classified in the subgenus Neothunnus from the tribe Thunini within family Scombridae along with blackfin (T. atlanticus) and yellowfin (T. albacares) tuna (Chow \& Kishino, 1995). It is the second smallest Thunnus species (Griffiths et al., 2019) but is also reported as the largest growing species among neritic tuna (Koya et al., 2018). T. tonggol is distributed exclusively in the Indo-Pacific region between $47^{\circ} \mathrm{N}$ and $33^{\circ} \mathrm{S}$ (Froese \& Pauly, 2011) and is one of the most economically important species in Southeast Asia (Itoh et al., 1996; Hidayat \& Noegroho, 2018). It represents essential, artisanal, and sustenance fisheries as one of the biggest sources of wild caught food (Frimodt, 1995; Collette, 2001). It is also considered an important sport-fish due to its large size and fighting ability (Griffiths et al., 2019).

The annual global catch of T. tonggol has tripled in the last 20 years (Griffiths et al., 2019). As a consequence, there was a marked decrease in its catch from 291,264 tonnes to 237,124 tonnes $(F A O, 2018)$ from 2007 to 2016. The highest catches reported were from Iran, Indonesia, Pakistan, Malaysia, Oman, Yemen, India, and Thailand (Pierre et al., 2014; Koya et al., 2018), where they were mainly caught using gillnet fleets operating in coastal waters. In Malaysia, the landing of neritic tuna consists of longtail tuna (T. tonggol), kawakawa (Euthynnus affinis), and frigate tuna (Auxis thazard and A. rochei) and contributed 5\% of the total marine landings (Mohd Faizal et al., 2019) with T. tonggol dominating, followed by kawakawa (E. affinis), and frigate tuna (A. thazard and A. rochei) (Samsudin et al., 2018). 
Basic population parameters, such as the number and distribution of stocks, as well as

76

77

78

79

80

81

82

population genetic diversity are very much needed for a sound management programme. For example, population stock data is essential to support resource recovery and to aid in delineating and monitoring populations for fishery management (Roldan et al., 2000; Kunal et al., 2014). Despite its important contributions, coupled with steadily increasing demands in recent years, there is little research on T. tonggol; it has, in fact, received less attention than other pelagic species in Southeast Asian waters (Willette et al., 2016), including Malaysia. A previous study on population genetics of T. tonggol from the northwest coast of India, based on the mitochondrial displacement loop (D-loop) marker, revealed low genetic differentiation between localities, which suggested a panmictic stock structure (Kunal et al., 2014). However, a study across a wider spatial coverage, also based on the D-loop marker, suggested geographical segregation for T. tonggol within the Indo-Pacific region (Willette et al., 2016). In other tuna species, such as the bigeye tuna (T. obesus), populations from the South China Sea, the Philippines Sea, and western Pacific Ocean consist of a single intermixing identity (Chiang et al., 2006), while yellowfin tuna (T. albacore) along the Indian coast, displayed multiple geographically distinct stocks (Kunal et al, 2013).

Population genetics is an essential tool to improve knowledge on stock delineation and population dynamics of exploited fish (Hauser \& Seeb, 2008). Genetic markers, like mtDNA, has proven to be one of the most efficient tools for evaluating intraspecific genetic variation and to describe population genetics study (Menezes at al., 2012; Tan et al., 2012; Nabilsyafiq et al., 2019). Moreover, it is also widely used in evolutionary genetics as markers for population history and to estimate divergence times among taxa (Tan et al., 2020). MtDNA is considered a sensitive and reliable marker (Hoolihan et al., 2006; Habib \& Sulaiman, 2016, 2017; Tan et al., 2019) due to its large quantity in the cell and elevated mutation rate [11.6 times higher than nuclear DNA 
98 (Allio et al., 2017)], a consequence of a non-existent or inefficient repair system. In addition, the 99 lack of recombination in mtDNA, coupled with relatively infrequent gene arrangement, makes it 100 a good choice for population genetics study (De Mandal et al., 2014).

The mtDNA NADH dehydrogenase subunit 5 (ND5) and the non-coding and highly polymorphic D-loop markers were adopted to conduct the first population genetics and phylogeographic studies among wild populations of T. tonggol in Malaysian coastal areas. The utilisation of D-loop as a population genetic marker has been widely documented in a plethora of marine species, including in tuna (Durand et al., 2005; Chiang et al., 2006; Santos et al., 2011). However, mtDNA ND5 gene is rarely used in marine species. Nevertheless, this protein-coding gene contains both slow and rapid evolving regions that permit its application in elucidating the genetic relationships among populations; for instance, six populations of the Persian sturgeon Acipenser persicus from the south Caspian Sea were found to be genetically differentiated, as inferred from the ND5 polymerase chain reaction-restriction fragment length polymorphism (PCR-RFLP) assay (Pourkazemi et al., 2012), meanwhile, moderate genetic differentiation among populations of masu salmon Oncorhynchus masou masou from Japan, Russia, and Korea was apparent based on ND5 and microsatellites markers (Yu et al., 2010). However, low genetic differentiation with high gene flow was detected between sampling locations of the Pearse's mudskipper (Periophthalmus novemradiatus) that inhabits Setiu Wetland, Terengganu, Malaysia 116 (Nabilsyafiq et al., 2019). waters based on mtDNA D-loop and ND5 markers, as well as further investigating the phylogeography of $T$. tonggol within the Indo-Pacific region, where samples from Taiwan 
121 and east coast: Andaman Sea; all haplotype sequences retrieved from GenBank) were included in

122 molecular analyses. The output from this study would be beneficial for the conservation and

123 management of this species.

\section{MATERIALS AND METHOD}

126

127

128

129

130

131

132

133

134

135

136

137

138

139

140

141

142

\section{Ethical statement}

Only a small clipping of the pectoral fin from each individual fish was collected from the local wet markets. This species is not in the IUCN list of endangered or protected species. As only dead specimens were sampled, no permit was required and no ethical consideration was linked to the study.

\section{Sample collection}

The specimens were collected from 11 fish landing sites in Malaysia and were morphologically identified following identification keys as described in Lim et al. (2018). This species can be differentiated from other Thunnus species by having a moderate length pectoral fin, reaching the origin of the second dorsal fin and blackish caudal fin (Lim et al., 2018). A small portion of pectoral fin of each individual was cut and preserved in 95\% ethanol and stored in a 1.5 $\mathrm{mL}$ centrifuge tube at $4-8^{\circ} \mathrm{C}$ until further analysis. Each catch locality was confirmed to be nonoverlapping (discrete geographical entity) based on feedback from the fishermen and was divided into four regions following Akib et al. (2015) (Table 1, Fig 1A). Additionally, four samples from Taiwan and 153 GenBank sequences of T. tonggol from the Indian waters (Fig. 1B) were included for phylogeographic analysis. 
143 Table 1 Sampling locations, coordinates, and collection date of 11 Thunnus tonggol populations

144 from the surrounding seas (in the Indo Pacific region) of Malaysia.

145

146 Figure 1 Sampling locations of Thunnus tonggol along the Malaysian coastal waters A) and 147 additional samples (B). (Modified from source http://www.supercoloring.com/coloring148 pages/malaysia-map)

$149 \mathrm{KP}=$ Kuala Perlis; PR=Pantai Remis; SB=Sungai Besar; TG=Pulau Kambing; KT=Kuantan; $150 \mathrm{~TB}=$ Tok Bali; KC=Kuching, $\mathrm{BT}=$ Bintulu; $\mathrm{MR}=$ Miri; KK=Kota Kinabalu; SM=Semporna; 151 TW=Taiwan; KH=Kochi; VR=Veraval; RN=Ratnagiri; $\mathrm{AD}=$ =Andaman Sea. Exact coordinates of 152 additional samples are unknown.

Genomic DNA isolation and Polymerase Chain Reaction (PCR) amplification

Genomic DNA was isolated from fin tissue by using the salt extraction method (Miller et al., 1988). The isolated DNA samples were then PCR amplified with the mtDNA partial displacement loop (D-loop) and NADH dehydrogenase subunit 5 (ND5). The following primers were used: (1) D-loop - Pro889U20 (5'-CCW CTA ACT CCC AAA GCT AG-3', forward) and TDKD1291L21 (5'-CCT GAA ATA GGA ACC AAA TGC-3', reverse) (Sulaiman \& Ovenden, 2009) (2) ND5 - L12321-Leu (5'-GGTCTTAGGAACCCAAAACTCTTGCTGCAA-3', forward) and H13396-ND5 (5'- CCTATTTTKCGGATGTCYTG-3', reverse) (Ruzainah, 2008). The PCR reaction mixture consisted of $2 \mu 1$ of the DNA template, $0.5 \mu 1$ of each primer, $12.5 \mu 1$ of MyTaq $^{\mathrm{TM}}$ Red Mix (Bioline), and 9.5 $\mu$ l sterilized ultrapure water $\left(\mathrm{ddH}_{2} \mathrm{O}\right)$ with a final volume in each tube of $25 \mu \mathrm{l}$. The temperature profile for the D-loop was: initial denaturation at $94^{\circ} \mathrm{C}$ for 5 min followed 
166 final hold at $4^{\circ} \mathrm{C}$. Amplification conditions for the ND5 gene were: initial denaturation at $94^{\circ} \mathrm{C}$ for

$1672 \mathrm{~min}$ followed by 35 cycles for $94^{\circ} \mathrm{C}$ for $20 \mathrm{~s}, 59^{\circ} \mathrm{C}$ for $20 \mathrm{~s}, 72^{\circ} \mathrm{C}$ for $1 \mathrm{~min} 30 \mathrm{sec}$, final extension

168 at $72^{\circ} \mathrm{C}$ for $5 \mathrm{~min}$, and final hold at $10^{\circ} \mathrm{C}$. PCR products were visualized on $1.7 \%$ agarose gels

169 stained with SYBR Safe to confirm their presence and estimate the size of DNA fragment

170 amplified. PCR products were then sent for sequencing (First BASE Laboratories Sdn Bhd,

171 Selangor Malaysia) in the forward direction only using an Applied Biosystem ABI3730x1

172 capillary-based DNA sequencer.

\section{Sequence editing and alignment}

174 Multiple sequences were aligned and edited using ClustalW implemented in MEGA 6.0 175 (Tamura et al., 2013). DNA sequences were verified for correct identity by using the Basic Local 176 Alignment Search Tool (BLAST) in the National Center for Biotechnology Information (NCBI) 177 database (http://blast.ncbi.nlm.nih.gov/Blast.cgi) before further analyses. All haplotypes were 178 deposited into GenBank under the accession numbers MK643829-644008 (D-loop) and 179 MN252922-252981 (ND5).

\section{Data analyses}

\section{Genetic diversity}

The complete aligned datasets were used to estimate the number of haplotypes, haplotype 183 diversity $(\mathrm{H})$, and nucleotide diversity $(\pi)$ in DnaSP 6.0 (Rozas et al., 2017). The polymorphic and parsimony informative sites were examined in MEGA 6.0.

\section{Phylogenetic and population level analyses}

The phylogenetic relationships among haplotypes were determined based on the

Maximum-Likelihood (ML) method implemented in MEGA 6.0. The best nucleotide substitution 
188 models with the lowest BIC score (Bayesian Information Criterion) for the D-loop and ND5 189 sequences were Tamura 3-parameter (T92) (Tamura, 1992) and Hasegawa-Kishino-Yano with 190 Gamma distribution and invariant sites $(\mathrm{HKY}+\mathrm{G}+1)$, respectively, as identified in MEGA 6.0. In 191 the case that the T92 and HKY models were unavailable in the BEAST and Arlequin software 192 packages (see below), the TN93 model (Tamura \& Nei, 1993) was used instead. The confidence 193 level for each node was assessed by 1000 bootstrap replications (Felsenstein, 1985). The Pacific 194 bluefin tuna T. orientalis (AB933631) was included as an out-group taxon for D-loop sequences, 195 while the Yellowfin tuna, T. albacares (KM588080) was included as out-group taxon for ND5 196 gene sequences. To infer the relationships among haplotypes from Malaysian waters, a minimum 197 spanning network (MSN) was constructed by using the median-joining method implemented in 198 NETWORK version 5.0.1.1 (Bandelt et al., 1999).

The population pairwise comparisons $\Phi_{\mathrm{ST}}$ for both datasets were determined using 200 Arlequin 3.5 software (Excoffier \& Lischer, 2010) and the statistically significant pairwise comparisons were tested with 10,000 permutations. Significant probability values were corrected by performing the False Discovery Rate Procedure (FDR) at $\alpha=0.05$ (Benjamini \& Hochberg, 1995). Further analysis of genetic differentiation among populations was extended for haplotypebased statistics $\left(\mathrm{H}_{\mathrm{ST}}\right)$, sequence-based statistics $\left(\mathrm{N}_{\mathrm{ST}}\right)$ (Lynch \& Crease, 1990), and $\mathrm{K}_{\mathrm{ST}}$ * with significance levels assessed using permutation tests with 1000 replicates (Hudson et al., 1992) in DnaSP 6.0. Using the same program, the estimation of gene flow (Nm) based on both haplotype and sequence statistics were calculated following Nei (1973) and Hudson et al. (1992), respectively. Genetic distance estimates between sampled populations were calculated in MEGA 6.0. 
212 demes, and demes within groups of demes (Excoffier et al., 2005), by using Arlequin 3.5 software.

213 The Mantel test in IBD v 1.52 (Isolation by Distance) (Mantel, 1967; Bohonak, 2002) was used to

214 investigate the correlation between genetic and geographical distance. Genetic distance was

215 represented by population pairwise $\Phi_{\mathrm{ST}}$ values while geographical distances between sampling

216 locations were measured by using Google Earth. Geographic distance was $\ln$ transformed and the

217 strength of the relationship was examined with reduced major axis regression $(10,000$

218 randomizations) in IBD v 1.52.

To understand its phylogeography within the Indo-Pacific region, GenBank sequences of MF592988-593012, Veraval (22) MF593027-593048, Ratnagiri and Veraval (92) KC313300MF593013-593026), and four samples from Taiwan (TW) were included in phylogenetic tree reconstruction, pairwise comparisons $\Phi_{\mathrm{ST}}$, AMOVA, and genetic distance analyses. Altogether 309 haplotype sequences were realigned, and ambiguous GenBank sequences were eliminated.

Only 152 Malaysian haplotypes (out of 180 haplotypes, see Results) were used after trimming the sequence to a final length of 388 base pairs (bp).

\section{Demographic history}

Historical demographic and spatial expansions were inspected in the T. tonggol 230 populations. Fu's $F_{\mathrm{S}}(F u, 1997)$ and Tajima's $D$ (Tajima, 1989) were adopted to analyse deviation

231 from neutrality. Historical demographic parameters, including the population before expansion 
$232\left(\Theta_{0}\right)$, after expansion $\left(\Theta_{1}\right)$, and relative time since population expansion $(\tau)$, were computed in

233 Arlequin 3.5. The values of time $(\tau)$ were transformed to estimate the actual time $(\mathrm{T})$ since

234 population expansion, using the equation $\tau=2 \mu \mathrm{t}$, where $\mathrm{t}$ is the age of the population in generations

235 and $\mu$ is the sequence mutation rate per generation. In the present study, a mutation rate of $3.6 \mathrm{x}$

$23610^{-8}$ mutation per site/year was applied for the D-loop (Donaldson \& Wilson, 1999) and 2\% per

237 million years for the ND5 (Brown et al., 1979). Bayesian skyline analyses were plotted using

238 BEAST version 2.2.0 (Bouckaert et al., 2019), where the changes in effective population size (Ne)

239 over time were tested. This enabled past demographic changes of T. tonggol to be inferred from

240 the current patterns of genetic diversity within a population (Drummond et al., 2005). Since there

241 was the absence of a population structure (see Results), a single population was modelled. The

242 input was prepared in BEAUti. The analysis was run for $10^{8}$ iterations with a burn-in of $10^{7}$ with

243 sampling every $10^{4}$ and a strict molecular clock. All operators were automatically optimized and

244 the results were generated using Tracer version 1.7.1 (Rambaut et al., 2018). powerful tool in quantifying population growth with limited sample sizes (Ramos-Onsins \& Rozas, 2002). In addition, the mismatch distribution was calculated in DnaSP 6.0. The pattern could be used to provide an insight of the past population demography (Chen et al., 2015). A population that has undergone recent expansion shows a unimodal distribution pattern, while a population in equilibrium shows a multimodal distribution pattern (Slatkin \& Hudson 1991; Rogers \& 253 Harpending, 1992). 


\section{RESULTS}

256

257

258

259

260

261

262

263

264

265

266

267

268

269

270

271

272

273

274

275

276

277

\section{Genetic diversity}

A total of 203 and 208 individuals were sequenced for the partial mtDNA D-loop and ND5 gene, respectively. The final alignment of D-loop sequences [416 base pairs (bp)] revealed 113 polymorphic sites (42 singletons and 71 parsimony informative sites), defining 180 haplotypes, where $14(7.78 \%)$ were found in two to five localities and the rest $(92.2 \%)$ were either private to a single locality or singleton haplotype. The ND5 sequences (855 bp) revealed 60 variable sites (34 parsimony informative sites, 26 singletons), defining 60 haplotypes, where 17 (27.9\%) were shared by two to 11 populations, five $(8.2 \%)$ were private to a single locality and $38(63.9 \%)$ were singleton haplotypes. The D-loop region was AT rich, while, ND5 gene sequences demonstrated higher percentages of CG (56\%). All populations of T. tonggol from Malaysian waters showed high haplotype diversity (D-loop: 0.990-1.000; ND5: 0.848-0.965) but low to moderate nucleotide diversity (D-loop: 0.0195-0.0250; ND5: 0.0017-0.0039) (Table 2).

Table 2 Molecular diversity, neutrality test, mismatch distribution, and goodness of fit tests for Thunnus tonggol populations based on D-loop and ND5 sequences

\section{Phylogenetic and population level analyses}

The phylogenetic reconstruction inferred from the mtDNA D-loop region and ND5 gene revealed a gene tree with mainly unsupported clades $(<50 \%)$ and obscure patterns of geographical segregation associated with genetic distribution (Fig. 2, Supplementary 1). This was aligned with 
278 the MSN haplotype network that showed no geographical partitioning among the populations

279 studied. Specifically, 180 D-loop haplotypes showed a complex reticulated network (Fig. 3), while

28060 ND5 haplotypes revealed a more clarified network pattern (Fig. 4). No dominant haplotype was

281 detected based on the D-loop marker, however, Hap004 and Hap005 were considered the most

282 abundant and common haplotypes, followed by Hap036 and Hap116. Among ND5 haplotypes,

283 Hap01 was the most dominant haplotype followed by Hap03, Hap15, Hap06, and Hap10. Hap01

284 was found at all sampling sites and was considered the ancestral haplotype. A network with an

285 ancestral haplotype typically shows a star-like or star-burst appearance with the ancestral

286 haplotype centred in it (Ferreri et al., 2011).

287

288

Figure 2 Maximun likelihood (ML) gene trees showing the relationship of Thunnus tonggol

haplotypes inferred from the (A) D-loop marker (tree was compressed for a better illusration) (B)

290

ND5 gene.

291

Branches were drawn to scale and bootstrap values $<50 \%$ were not shown. (The original D-loop

ML tree was presented in Supplementary 1). All regions = SCS-1, SCS-2, SOM, CS, WCIO, ECIO,

TW; WCIO = west coast Indian Ocean

Supplementary 1 Unscaled ML tree showing the relationship of Thunnus tonggol haplotypes inferred from the D-loop marker.

Hap001-042 (SCS-1), 043-085 (SOM), 086-104 (CS), 108-152 (SCS-2), 153-166 (ECIO), 168296 (WCIO), 297-300 (TW).

Figure 3 Haplotype network diagram inferred from the D-loop region. 
301 Node size corresponds to the haplotype frequencies; minimum node size is one individual. Black

302 dot represents the median vector. Dashed line represents a nucleotide mutation. Populations:

$303 \mathrm{KP}=$ Kuala Perlis; PR=Pantai Remis; SB=Sungai Besar; TG=Pulau Kambing; KT=Kuantan;

$304 \mathrm{~TB}=$ Tok Bali; KC=Kuching; $\mathrm{BT}=$ =Bintulu; MR=Miri; KK=Kota Kinabalu; SM=Semporna.

305

306 Figure 4 Haplotype network diagram inferred from the ND5 gene.

307 Node size corresponds to the haplotype frequencies; minimum node size is one individual. Black

308 dot represents the median vector. Dashed line represents a nucleotide mutation. Populations:

$309 \mathrm{KP}=$ Kuala Perlis; PR=Pantai Remis; SB=Sungai Besar; TG=Pulau Kambing; KT=Kuantan;

$310 \mathrm{~TB}=$ Tok Bali; KC=Kuching; $\mathrm{BT}=$ Bintulu; $\mathrm{MR}=$ Miri; KK=Kota Kinabalu; SM=Semporna.

Pairwise comparison $\Phi_{\mathrm{ST}}$ analysis corroborated the low and non-significant population 314 structure of T. tonggol from Malaysian waters [D-loop: -0.0324 to 0.1191 (Table 3); ND5: -0.0254 to 0.0739 (Table 4)], except for seven and a single significant pairwise comparison involving BT, based on the D-loop and ND5 sequences, respectively. Further genetic differentiation assessment based on $\mathrm{H}_{\mathrm{ST}}$ (D-loop: 0.0033; ND5: 0.0034), $\mathrm{N}_{\mathrm{ST}}$ (D-loop: 0.0113; ND5: 0.0062) and $\mathrm{K}_{\mathrm{ST}}$ * (Dloop: 0.0064; ND5: 0.0049) produced low and not significant values, which corresponds with a high level of gene flow (Nm) among Malaysian T. tonggol populations (D-loop: 145.69 and ND5: 146.01 for haplotype-based statistic; D-loop: 43.72 and ND5: 102.46 for sequence-based statistic).

321 Correspondingly, the pairwise genetic distances among populations also exhibit relatively low 322 values ranging from 0.0197 to 0.0251 (D-loop) and 0.0020 to 0.0038 (ND5). The hierarchical 323 AMOVA indicated that more than $99 \%$ of the total genetic variation in Malaysian T. tonggol was 
324 contributed by genetic differences within populations. Attempts to identify if population

325 subdivisions exist among the $T$. tonggol populations (BT vs other populations) returned a non-

326 significant $F_{\mathrm{CT}}$ value with less than $1 \%$ contribution to the total genetic variation, while more than

$32799 \%$ of the total genetic variation was contributed within populations, based on both datasets. The

328 Mantel Test also supported earlier findings, demonstrating no correlation between genetic

329 differentiation (pairwise $\Phi_{\mathrm{ST}}$ value) and geographical distance (D-loop: $\mathrm{r}=-0.3763, \mathrm{P}=0.08$ and

330 ND5: $\mathrm{r}=-0.0050, \mathrm{P}=0.43$ ) among Malaysian populations.

Table 3 Pairwise $\Phi_{\mathrm{ST}}$ estimates (below diagonal) and genetic distance (upper diagonal) between sampling sites of Thunnus tonggol inferred by the mtDNA D-loop region.

Table 4 Pairwise $\Phi_{\mathrm{ST}}$ estimates (below diagonal) and genetic distance (upper diagonal) between sampling sites of Thunnus tonggol inferred by the mtDNA ND5 gene. (ECIO), and some of the west coast of the Indian Ocean (WCIO) were clustered with the Malaysian haplotypes, while some other WCIO haplotypes were placed into another clade with high bootstrap support (Fig. 2A, Supplementary 1). ML tree partitioning was partly in agreement with the pairwise comparisons $\Phi_{\mathrm{ST}}$, where TW was not significantly structured for Malaysia, ECIO nor WCIO. In contrast, all pairwise comparisons involving ECIO and WCIO against Malaysian's populations were statistically significant after FDR correction at $\alpha=0.05$, except for WCIO-KT 
346 0.05) (Table 3). A hierarchical AMOVA revealed the existence of genetic subdivision between the

347 Indian Ocean and Malaysian waters $\left(F_{\mathrm{CT}}: 0.09, \mathrm{P}<0.05\right)$, yet $90.01 \%$ of the genetic variation

348 within the Indo-Pacific region was contributed by genetic differences within populations. Pairwise

349 genetic distances between TW and Malaysian populations ranged from 0.0181 to 0.0219 , while

350 the genetic distances were relatively higher for pairwise comparisons involving ECIO and WCIO,

351 i.e. from 0.0238 to 0.0371 (Table 3 ).

\section{Demographic history}

353

Negative values of Tajima's $D$ and Fu's $F_{\mathrm{S}}$ (all significant at $\left.\mathrm{P}<0.05\right)$ neutrality tests were

354

355

356

357

358

359

360

361

362

363

364

365

366 detected in all populations inferred from both the mtDNA D-loop and ND5 gene (Table 2). Large differences in population sizes before $\left(\theta_{0}\right)$ and after expansion $\left(\theta_{1}\right)$ were detected, i.e (on average) 0.116 and 54915.300 based on D-loop sequences, while 0.103 and 81838.400 were based on the ND5 gene marker (Table 2). Corresponding to the $\tau$ value of 2.321 (ND5) and 8.514 (D-loop) (Table 2), the calculated expansion time for T. tonggol in Malaysian waters was 67,865 and 284,252 years ago inferred by ND5 and D-loop markers, respectively Bayesian skyline plot (BSP) analysis revealed two significant increases in effective population size that occurred 200,000 and 950,000 years ago based on the D-loop marker (Fig. 5A), while continuous expansion started 150,000 years ago with a more recent expansion around 100,000 years ago based on the ND5 gene marker (Fig. 5B). Goodness of fit tests (Hri and SSD) exhibited non-significant values for the overall samples $(\mathrm{P}>0.05)$ (Table 2). Population demographic analysis of $T$. tonggol matched a unimodal distribution for overall samples (Fig. 6). 
367 Figure 5 Bayesian Skyline Plots of the mtDNA (A) D-loop marker and (B) ND5 gene of Thunnus 368 tonggol populations in Malaysia.

369 The $\mathrm{Y}$-axis indicates effective population size $(\mathrm{Ne}) \times$ generation time, while the $\mathrm{X}$-axis indicates mean

370 time in thousands of years before present. The thick line represents the average and the blue band 371 represents the standard error.

372

373 Figure 6 Mismatch distributions (pairwise number of differences) for the mtDNA (A) D-loop 374 region (B) ND5 gene of Thunnus tonggol showing the expected and observed pairwise 375 differences between sequences with the respective frequencies.

376

377

378

379

\section{DISCUSSION}

\section{Genetic diversity}

According to Grant \& Bowen (1998), the past demographic history of populations can be clarified based on their contemporary haplotype diversity $(\mathrm{H})$ and nucleotide diversity $(\pi)$. These two sensitive indices are the basis of genetic diversity estimation of a population (Nei \& $\mathrm{Li}, 1979)$. In this study, all populations of T. tonggol showed high haplotype diversity (D-loop: 0.990-1.000; ND5: $0.848-0.965$ ) but low to moderate nucleotide diversity (D-loop: 0.0195-0.0250; ND5: 0.0017-0.0039) (Table 2). High haplotype diversity, coupled with low nucleotide diversity, indicates a large population size that has undergone recent population expansion, which allows the retention of new alleles in the population but without sufficient time for accumulation of more nucleotide substitutions among haplotypes (Grant \& Bowen, 1998; Chen et al., 2015; DelrieuTrottin et al., 2017; Nabilsyafiq et al., 2019). These results were in agreement with previous findings of several pelagic fishes, including the spotted mackerel, Scomber australasicus 
$391(\mathrm{H}=0.996, \pi=0.007)$ (Tzeng, 2007), yellowfin tuna $T$. albacares $(\mathrm{H}=0.997, \pi=0.035)$, skipjack tuna

392 Katsuwonus pelamis $(\mathrm{H}=0.999, \pi=0.084)$ (Ely et al., 2005), and longtail tuna, T. tonggol $(\mathrm{H}=0.999$,

$393 \pi=0.0016$ ) (Willette et al., 2016). Furthermore, the wide difference in nucleotide variability

394 estimates between the two markers was consistent with the findings of Viñas \& Tudela (2009),

395 where the D-loop region had a ten-fold higher value of nucleotide diversity compared to the 396 mtDNA ND5 gene.

397 Phylogenetic and population level analyses

Populations of T. tonggol from Malaysian waters exhibited an absence of geographical 399 structure associated with mtDNA sequences, as evidenced by the single-clade gene trees (Fig. 2, Supplementary 1), ambiguous genetic partitioning of haplotype networks (Figs. $3 \& 4$ ), low and 401 non-significant values of pairwise $\Phi_{\mathrm{ST}}$ (Table $3 \& 4$ ) (except for several comparisons involving BT population), high contribution of within population variation through AMOVA, and nonsignificant correlation between genetic differentiation and geographical distance. These results strongly suggest that the T. tonggol populations in Malaysian waters were panmictic with shallow genetic structure due to high gene flow, similarly reported in other studies of the same species

(Kunal et al., 2014; Willette et al., 2016) and several other species (Santos et al., 2011). Wright (1931) suggested that the level of genetic differentiation among populations is related to the rate of evolutionary processes, like migration, mutation, and drift. Thus, a highly migratory species with a large population size, such as T. tonggol, is predicted to show limited population 410 partitioning. BT population showed significant genetic structure from the rest (except TG and MR) and SB, inferred from the D-loop and ND5 sequences respectively, based on the population

412 pairwise $\Phi_{\mathrm{ST}}$ analysis, however, all other analyses suggested genetic homogeneity with other $T$. 
414 of algorithms or characters used in the various analyses, perhaps a different emphasis on nucleotide

415 versus haplotype diversity.

416 Pelagic fish in the marine realm are well-known to exhibit little genetic divergence (Ely et

417 al., 2005). The weak genetic structure observed in T. tonggol within the pelagic environment is

418 typical of pelagic fish due to their biological and life histories (Fauvelot \& Borsa, 2011; Pedrosa-

419 Gerasmio et al., 2014). T. tonggol spawns during the monsoon season (Koya et al., 2018) where

420 the ocean circulation shift (upwelling and down welling) during this season would enrich the water

421 at the surface and thus lead to the growth of plankton (Yohannan \& Abdurahiman, 1998). Although

422 T. tonggol is not a plankton feeder, the plankton bloom somehow enriches the food resources for

423 other fish that become the prey of T. tonggol, hence, creating an optimal spawning ground for the

424 species. T. tonggol is believed to spawn close to coastal waters (Nishikawa \& Ueyanagi, 1991),

425 thus the dynamic movement of waters during monsoon, not only helps in circulation of rich

426 nutrients, but also in the larvae dispersal that could span a larger area (Madhavi \& Lakshmi, 2012).

427 Another possible explanation for the absence of limited gene flow among populations is the pattern

428 of migration in the adult stage. In addition to the high dispersal potential during egg and larval

429 stages, adults are characterised by high manoeuvrability during seasonal migration.

An earlier study by Willette et al. (2016) showed delineation of the Indian Ocean versus

the South China Sea (samples were collected from Vietnam, Indonesia, and the Philippines) but

without representatives from Malaysian waters. In the present study, based on the increased sample

433 populations on a finer scale within this biogeographical region and GenBank sequences, we

between the coast of India and Malaysian waters, as evidenced in the ML tree (Fig. 2A, 
437 another possible break between ECIO and WCIO based on results in the ML tree (Fig. 2A,

438 Supplementary 1) and pairwise comparisons $\Phi_{\mathrm{ST}}$, though the moderate pairwise $\Phi_{\mathrm{ST}}$ value is not

439 significant (Table 3). However, the phylogenetic relationship of T. tonggol from Malaysian waters

440 and other regions of the South China Sea remains unknown due to the limited genetic data and

441 unavailability of the haplotype sequences from the study by Willette et al. (2016) in the public

442 database. We postulated that close genetic relationships would be expected, based on the recent

443 findings regarding the absence of genetic subdivision between TW and Malaysian T. tonggol.

444 Future studies should include more detailed sampling within the Andaman Sea and adjacent waters

445 to substantiate this.

\section{Demographic history}

Historical events during the Pleistocene epoch could have shaped the genetic diversification of T. tonggol populations observed in the present study. All relevant statistical tests implied a scenario of past population/ demographic expansion in the absence of background selection. Negative Fu's $F_{\mathrm{S}}$ values signified the alterations caused by population expansion and/ or selection $(\mathrm{Fu}, 1997)$, which was further supported by Tajima's D that implied a notable population growth or genetic hitchhiking in a background of recent excess mutations (Tajima, 453 1989). Likewise, the non-significant sum of squared deviations (SSD) and Harpending's raggedness index (Hri) indicated the occurrence of population expansion in T. tonggol (Kunal et al., 2014) that inhabits Malaysian waters. Furthermore, the star-like pattern of the median-joining network (Fig. 4) and unimodal pattern of mismatch distribution (Fig. 6) further support the

457 occurrence of a sudden demographic expansion during recent history of the taxa (Slatkin \& Hudson 458 1991; Rogers \& Harpending 1992; Ferreri et al., 2011; Kunal et al., 2014; Chen et al., 2015; Pedrosa-Gerasmio et al., 2014). 

rapid population expansion of $T$. tonggol in the past as also reported in a previous study of 462 populations from India (Kunal et al., 2014). The overall $\tau$ value observed in Malaysia was much 463 lower than T. tonggol populations from Indian waters, which was 21.26. The estimated time for population expansion in Indian waters was 593,334 years before the present (Kunal et al., 2014),

465 as compared to 67,865 and 284,252 years ago inferred by the ND5 and D-loop markers, 466 respectively, for $T$. tonggol from Malaysian waters. This suggests that $T$. tonggol in the Indian 467 region underwent earlier expansion, with subsequent large population retention. In this study, the 468 ND5 gene marker was able to detect a more recent population expansion of T. tonggol populations 469 in Malaysian waters around 70,000 years ago (based on tau value) and 100,000 years ago (based 470 on BSP analysis). Based on the D-loop marker, two expansion events were detected, where the 471 first round occurred around 200,000 years ago (based on BSP analysis) or 284,000 years ago 472 (based on tau value) (during middle Pleistocene (126,000-781,000 years before present) (Saul, 473 2016)) and the second round occurred around 950,000 years ago (based on BSP analysis) (during 474 early Pleistocene) (Fig. 5). In general, both markers were able to detect population expansion that 475 occurred around 200,000 years ago (ND5 gene marker indicated population expansion started 476 before 150,000 years ago).

\section{Implication for fisheries management}

To date, there is limited information on the population structure of T. tonggol, especially 480 in Malaysia, and from the management point of view, this is a critical issue. The present study provides the first baseline population genetic data on T. tonggol populations in Malaysian waters, which is important information for management planning by authorities. 
pools for a sustainable harvest. Molecular analyses, in complement with other approaches, may serve as a reliable measurement for an efficient preservation strategy (BjØrnstad \& Ried, 2002; Toro et al., 2003). The genetic data suggest that T. tonggol in Malaysia forms a panmictic population as observed by the wide distributional range of this species and non-significant low $\Phi_{\mathrm{ST}}$ values among the populations studied, thus suggesting a single evolutionary significant unit

(ESU). However, this study was based on mitochondrial markers and therefore, restricted to only the pattern of maternal inheritance. For a holistic genetic perspective of bi-parental inheritance, co-dominant markers, such as microsatellites, should be included.

492

493

494

495

496

497

498

499

500

501

502

503

504

\section{CONCLUSIONS}

The T. tonggol populations in Malaysian waters revealed the absence of population structure as inferred by both mtDNA markers and therefore, could be regarded as a single stock unit for management purposes based on the current data. Their inferred demographic history suggests that $T$. tonggol populations expanded significantly during the middle and early Pleistocene. Overall, this study is a critical first baseline, providing insights for stock management of this neritic species in Malaysian coastal areas. Coupled with other related information, the assimilation of this genetic information could aid the development of effective management plans in the future, not only in Malaysia but also in neighbouring countries sharing the same waters. Finally, this has contributed further insights into genetic locality, delineating the species within the Indo-Pacific biogeographical region.

\section{ACKNOWLEDGEMENTS}


505 We thank the Ministry of Higher Education (MOHE) for funding this research under grant 506 FRGS/1/2016/WAB13/UMT/03/1. We highly appreciate assistance by the officers and crew of the 507 research vessel MFRDMD/SEAFDEC and Department of Fisheries (DoF) Malaysia for sharing 508 their expertise and knowledge and also facilitating sample collections. We are also grateful to our 509 laboratory colleagues for their technical assistance. We are forever grateful to Dr Adelyna Mohd 510 Akib and her PhD student, Mr. Danial Hariz for their valuable guidance and comment regarding 511 Bayesian Skyline Plot analyses.

512

513 ADDITIONAL INFORMATION AND DECLARATION

\section{Funding}

515 This work was financially supported by Ministry of Higher Education (MOHE). The funders were 516 not involved in study design, data collection and analysis or preparation of the manuscript.

517 Grant Disclosures

518 The following grant information was disclosed by the authors:

519 Ministry of Higher Education (MOHE): FRGS/1/2016/WAB13/UMT/03/1

520 Competing Interests

521 The authors declare there are no competing interests.

522

523

REFERENCES

524

Akib NAM, Tam BM, Phumee P, Zainal Abidin M, Tamadoni S, Mather PB, Mohd Nor SA. 525 2015. High connectivity in Rastralliger kanagurta: Influence of historical signatures and migratory behaviour inferred from mtDNA Cytochrome b. PloS ONE 10 (3): 1-18. 
527 Allio R, Donega S, Galtier N, Nabholz B. 2017. Large variation in the ratio of mitochondrial to

528

529

530

531

532

533

534

535

536

537

538

539

540

541

542

543

544

545

546

547

548

549 nuclear mutation rate acrooss animals: implications for genetic diversity and the use of mitochondrial DNA as a molecular marker. Molecular Biology and Evolution 34(11): 2762-2772.

Bandelt HJ, Forster P, Rohl A. 1999. Median-joining networks for inferring intraspecific phylogenies. Molecular Biology and Evolution 16: 37-48. pmid:10331250

Benjamini Y, Hochberg Y. 1995. Controlling the false discovery rate: a practical and powerful approach to multiple testing. Journal of the Royal Statistical Society B 57: 289-300. doi: 10.2307/2346101

BjØrnstad G, Ried KH. 2002. Evaluation of factor that affecting individual assigment precision using microsatellite data from horse breeds and simulated breed crosses. Animal Genetics 33: $264-270$.

Bohonak AJ. 2002. IBD (Isolation by distance): a program for analyses of isolation bydistance. Journal of Heredity 93: 153-154 DOI 10.1093/ jhered/93.2.153

Bouckaert R, Vaughan TG, Barido-Sottani J, Duchêne S, Fourment M, Gavryushkina A. 2019. BEAST 2.5: An advanced software platform for Bayesian evolutionary analysis. PLoS computational biology 15(4): e1006650.

Brown WM, George M, Wilson AC. 1979. Rapid evolution of animal mitochondrial DNA. Proceedings of the National Academy of Science of the United States of America 76(4): 1967-1971. DOI: 10.1073/pnas.76.4.1967

Chen W, Hong W, Chen S, Wang Q, Zhang Q. 2015. Population genetic structure and demographic history of the mudskipper Boleophthalmus pectinirostris on the northwestern pacific coast. Environmental Biology of Fishes 98: 845-856.

Peer) reviewing PDF | (2019:08:40038:4:0:NEW 9 Jul 2020) 
550 Chiang HC, Hsu CC, Lin HD, Ma GC, Chiang TY, Yang HY. 2006. Population structure

551 of bigeye tuna (Thunnus obesus) in the South China Sea, Philippine Sea and western

552 Pacific Ocean inferred from mitochondrial DNA. Fisheries Research 79: 219-225.

553 Chow S, Kishino H. 1995. Phylogenetic Relationships Between Tuna Species of the Genus

554 Thunnus (Scombridae: Teleostei): Inconsistent Implications from Morphology, Nuclear 555 and Mitochondrial Genomes. Journal of Molecular Evolution 41: 741-748.

556 Collette BB. 2001. Scombridae. Tunas (also, albacore, bonitos, mackerels, seerfishes, and wahoo).

557

558

559

560

561

562

563

564

565

566

567

568

569

570

571

572

De Mandal S, Chhakchhuak L, Gurusubramaniam G, Kuman NS. 2014. p. 3721-3756. In K.E. Carpenter and V. Niem (eds.) FAO species identification guide for fishery purposes. The living marine resources of the Western Central Pacific. Vol. 6. Bony fishes part 4 (Labridae to Latimeriidae), estuarine crocodiles. FAO, Rome. [Retrived online]

Mitochondrialmarkers for identification and phylogenetic studies in insects - A review. DNA Barcodes 2; 1-9. DOI: 10.2478/dna-2014-0001.

Delrieu-Trottin E, Mona S, Maynard J, Neglia V, Veuille M, Planes S. 2017. Population expansions dominate demographic histories of endemic and widespread Pacific reef fishes. Scientific Reports 7: 40519.

Donaldson KA, Wilson RR. 1999. Amphi-Panamaic geminates of snook (Percoidea: Centrapomidae) provide a calibration of the divergence rates in the mitochondrial DNA control region of fishes. Molecular Phylogenetic and Evolution 13: 203-211.

Drummond AJ, Rambaut A, Shapiro B, Pybus OG. 2005. Bayesian coalescent inference of past population dynamics from molecular sequences. Molecular Biology and Evolution 22(5): 1185-1192. http://dx.doi.org/10.1093/molbev 
573 Durand JD, Collet A, Chow S, Guinand B, Borsa P. 2005. Nuclear and mitochondrial DNA

574

575

576

577

578

579

580

581

582

583

584

585

586

587

588

589

590

591

592

593

594

595

markers indicate unidirectional gene flow of Indo-Pacific to Atlantic bigeye tuna (Thunnus obesus) populations, and their admixture off southern Africa. Marine Biology 147: $313-322$.

Ely B, Viñas J, Bremer JRA, Black D, Lucas, Covello K. 2005. Consequences of the historical demography on the global population structure of two highly migratory cosmopolitan marine fishes: the yellowfin tuna (Thunnus albacares) and the skipjack tuna (Katsuwonus pelamis). BMC Evolutionary Biology 5(1): 19 DOI:10.1186/1471-2148-5-19.

Excoffier L, Laval G, Schneider S. 2005. Arlequin ver 3.0: an integrate software package for population genetics a data analysis. Evolutionary Bioinformatics 1: 47-50

Excoffier L, Lischer HEL. 2010. Arlequin suite ver 3.5: A new series of programs to perform population genetics analyses under Linux and Windows. Molecular Ecology Resources 10(3): 564-567. DOI: 10.1111/j.1755-0998.2010.02847.x.

FAO. 2018. 'Fishery and Aquaculture Statistics. Global Capture Production 1950-2016 (FishstatJ).' (FAO: Rome, Italy.)

Fauvelot C., Borsa P. 2011. Pattern of genetic isolation in narrow-barred Spanish mackerel (Scomberomus commerson) across Indo-West Pacific. Biological Journal of the Linnean Society 104: 886-902.

Felsenstein J. 1985. Confidence limits on phylogenies: An approach using the bootstrap. Evolution 39: 783-791.

Ferreri M, Qu W, Han B. 2011. Phylogenetic network: A tool to display character conflict and demographic history. African Journal of Biotechnology 10(60): 12799-12803. DOI:10.5897/AJB11.010 
596 Frimodt C. 1995. Multilingual illustrated guide to the world's commercial warmwater fish. 597 Fishing News Books, Osney Mead, Oxford, England. 215 p. [Retrieved online iotc]

598

599

600

601

602

603

604

605

606

607

608

609

610

611

612

613

614

615

616

617

Froese R, Pauly D. 2011. FishBase. World Wide Web Electronic publication. http://www.fishbase.org/

Fu YX. 1997. Statistical tests of neutrality of mutations against population growth, hitchhiking and background selection. Genetics 147(2): 915-925.

Grant WS, Bowen, BW. 1998. Shallow population histories in deep evolutionary lineages of marine fishes: insights from sardines and anchovies and lessons for conservation. Journal of Heredity 89(5): 415-426. https://doi.org/10.1093/jhered/89.5.415

Griffiths SP, Zischke MT, van der Velde T, Fry GC. (2019). Reproductive biology andestimates of length and age at maturity of longtail tuna (Thunnus tonggol) in Australian waters based on histological assessment. Marine and Freshwater Research 70: "Online Early" DOI 10.1071/MF18469.

Habib A, Sulaiman Z. 2016. High genetic connectivity of narrow-barred Spanish mackerel (Scomberomorus commerson) from the South China, Bali and Java Seas. Zoology and Ecology 26 (2): 93-99.

Habib A, Sulaiman Z. 2017. Mitochondrial DNA analyses of narrow-barred Spanish mackerel (Scomberomorus commerson) sampled from the Arabian Sea, the Bay of Bengal, and the Indo-Malay archipelago. Zoology and Ecology 27 (3-4): 245-250.

Harpending HC. 1994. Signature of ancient population growth in a low-resolution mitochondrial DNA mismatch distribution. Human Biology 66(4): 591-600. PMID: 8088750

Peer) reviewing PDF | (2019:08:40038:4:0:NEW 9 Jul 2020) 
618 Hauser L, Seeb JE. 2008. Advances in molecular technology and their impact on fisheries 619 genetics. Fish and Fisheries 9: 473-486.

620

621

622

623

624

625

626

627

628

629

630

631

632

633

634

635

636

637

638

639

640 the South China Sea. BAWAL: Widya Riset Perikanan Tangkap 10 (1): 17-28.

Hoolihan JP, Anandh P, Herwerden LV. 2006. Mitochondrial DNA analyses of narrow barred Spanish mackerel (Scomberomorus commerson) suggest a single genetic stock in the ROPME sea area (Arabian Gulf, gulf og Oman, and Arabian Sea). ICES Journal of Marine Science 63: 000-000.

Hudson RR, Boos DD, Kaplan NL. 1992. A statistical test for detecting geographic sub division. 9(1): 138-151.

Itoh T, Tsuji S, Chow S. 1996. Catch information of longtail tuna, Thunnus tonggol, in Japan. Meeting document. FAO.

Koya KM, Rohit P, Abdussamad E, Abdul Azeez P, Vase VK, Bharadiya Sangita A. 2018. Reproductive biology, diet and feeding pattern of longtail tuna Thunnus tonggol (Bleeker, 1851) in the north-eastern Arabian Sea off Gujarat, India. Indian Journal of Fisheries 65(2): $16-25$.

Kunal SP, Kumar G, Menezes MR, Meena RM. 2013. Mitochondrial DNA analysis reveals three stocks of yellowfin tuna Thunnus albacares (Bonnaterra, 1788) in Indian waters. Conservative Genetics 14: 205-213.

Kunal SP, Kumar G, Menezes R, Meena RM. 2014. Genetic homogeneity in longtail tuna Thunnus tonggol (Bleeker, 1951) from the northwest coast of India inferred from direct sequencing analysis of the mitochondrial DNA D-loop region. Marine Biology Research 10: $738-743$. 
641 Lim APK, Ahmad A, Nor Azman, Mohd Saki N. 2018. Field Guide to Fishes and 642 Crustacean of the Southeast Asian Region. SEAFDEC/MFRDMD/39: Malaysia. 246p

643

644

645

646

647

648

649

650

651

652

653

654

655

656

657

658

659

660

661

662

663

Lynch M, Crease TJ. 1990. The analysis of population survey data on DNA sequence variation. Molecular Biology and Evolution 7(4): 377-394.

Madhavi R, Lakshmi TT. 2012. Community ecology of metazoan parasites of Indian mackerel Rastralliger kanagurta (Scombridae) from the coast of Visakhapatnam, Bay of Bengal. Journal of Parasitic Diseases 36(2): 165-170.

Mantel N. 1967. The detection of disease clustering and a generalized regression approach. Cancer Research 27: 209-220.

Menezes MR, Kumar G, Kunal SP. 2012. Population genetic structure of skipjack tuna Katsuwonus pelamis from the Indian coast using sequence analysis of the mitochondrial DNA Dloop region. Journal of Fish Biology 80: 2198-212.

Miller SA, Dykes DD, Polesky. 1988. A simple salting out procedure for extracting DNA from human nucleated cells. Nucleic Acids Research 16: 1215.

Mohd Faizal E, Jamon S, Jamaludin NA, Abu Halim NH. 2019. Status of neritic tuna fishery and some biological aspects of Kawakawa (Euthynnus affinis) in the northern part of Peninsular Malaysia. IOTC-2019-WPNT09-13.

Nabilsyafiq MH, Gan HM, Abd. Mazlan AG, Mat Jaafar TNA, Danish-Daniel M., Sung YY, Tan MP. 2019. ND5 gene marker reveals recent population expansion of wild Pearse's mudskipper (Periophthalmus novemradiatus Hamilton) inhabits Setiu Wetlands in East Peninsular Malaysia. Malaysian Applied Biology 48 (1): 87-93.

Nei M, Li HW. 1979. Mathematical model for studying genetic variation in term of restriction endonucleases. PNAS 76: 5269 - 5273. 
664 Nei M. 1973. Analysis of gene diversity in subdivided populations. Proceedings of the National 665 Academy of Sciences of the United States of America 70(12) Part I: 33213323

666 Nishikawa Y, Ueyanagi, S. 1991. Morphological development of larvae of longtail tuna. 667 Bulletin National Research Institute of Far Seas Fisheries. 28: 1-13.

668 Pedrosa-Gerasmio IR, Agmata AB, Santos MD. 2014. Genetic diversity, population genetc 669 structure and demographic history of Auxis thazard (Perciformes), Selar crumenophthalmus (Perciformes), Rastralliger kanagurta (Perciformes) and Sardinella lemuru (Clupeiformes) in Sulu-Celebes Sea inferred by mitochondrial DNA sequences. Fisheries Research 162: 64-74 DOI 10.1016/j.fishres.2014.10.006

Pierre L, Geehan J, Herrera M. 2014. Review of the Statistical Data Available for Bycatch Species. IOTC-2014-WPNT04-07 1: 17-19

Pourkazemi M, Khoshkholgh M, Nazari S, Azizzadeh Pormehr L. 2012. Genetic relationships among collections of the Persian sturgeon, Acipenser persicus, in the south Caspian Sea detected by mitochondrial DNA-Restriction fragment length polymorphisms. Caspian Journal of Environmental Science 10 (2): 215-226

Rambaut A, Drummond AJ, Xie D, Baele G and Suchard MA. 2018. Posterior summarisation in Bayesian phylogenetics using Tracer 1.7. Systematic Biology. DOI:10.1093/sysbio/syy032

Ramos-Onsins SE, Rozas J. 2002. Statistical properties of new neutrality tests against population growth. Molecular Biology and Evolution 19(12): 2092-2100.

Rogers AR, Harpending H. 1992. Population growth makes waves in the distribution of pairwise genetic differences. Molecular Biology and Evolution. 9 (3): 552-569. 
686 Roldan MI, Perrotta RG, Cortey M, Pla C. 2000. Molecular and morphologi approaches

687 to discrimination of variability patterns in chub mackerel, Scomber japonicus. Journal 688 of Experimental Marine Biology and Ecology 253: 63-74.

689 Rozas J, Ferrer-Mata A, Sánchez-DelBarrio1 JC, Guirao-Rico, S, Librado P, Ramos-Onsins

690

691

692

693

694

695

696

697

698

699

700

701

702

703

704

705

706

707

708

SE, Sánchez-Gracia1 A. 2017. DnaSP v6: DNA SequencePolymorphism Analysis of Large Datasets. Molecular Biology and Evolution 34: 3299-3302.

Ruzainah A. 2008. Population genetic studies of marble goby Oxyleotris marmoratus (Bleeker, 1852) in Malaysia using microsatellite and mitochondrial DNA markers. PhD thesis, Universiti Sains Malaysia.

Samsudin B, Sallehudin J, Tengku, Balkis TS, Nor Azlin M. 2018. Malaysia national report to the scientific committee of the Indian ocean tuna commission for 2018. Information on fisheries, research and statistics 2018 SC21-NR15.

Santos MD, Starger CJ, Toha AHA. 2011. Comparative phylogeography of the Coral Triangle and implications for marine management. Journal of Marine Biology 396982: 1-14.

Saul H. 2016. The Nepalese Himalayas in prehistoric context: A review of their role in Eurasian exchange networks and domestication. History Compass 14: 191-205.

Slatkin M, Hudson RR. 1991. Pairwise comparisons of mitochondrial DNA sequences in stable and exponentially growing populations. Genetics. 129(2): 555-562 PMID: 1743491

Sulaiman ZH, Ovenden JR. 2009. Population genetic evidence for the east-west division of the narrowbarred Spanish mackerel (Scomberomorus commerson,Perciformes: Teleostei) along Wallace's Line. Biodiversity and Conservation 19: 563-574.

Tajima F. 1989. Statistical method for testing the neutral mutation hypothesis by DNA polymorphism. Genetics 123: 585-595.

Peer] reviewing PDF | (2019:08:40038:4:0:NEW 9 Jul 2020) 
709 Tamura K, Nei M. 1993. Estimation of the number of nucleotide substitutions in the control 710 region of mitochondrial DNA in humans and chimpanzees. Molecular Biology and Evolution 10 (3): 512-526.

712 Tamura K, Stecher G, Peterson D, Filipski A, Kumar S. 2013. MEGA6: Molecular

713

714

715

716

717

718

719

720

721

722

723

724

725

726

727

728

729

730

731

evolutionary genetics analysis version 6.0. Molecular Biology and Evolution 30: 27252729.

Tamura K. 1992. Estimation of the number of nucleotide substitutions when there are strong transition-transversion and $\mathrm{G}+\mathrm{C}$ content biases. Molecular Biology and Evolution 9(4): 678-687.

Tan MP, Amornsakun T, Siti Azizah MN, Habib A, Sung YY, Danish-Daniel M. 2019. Hidden genetic diversity in snakeskin gourami, Trichopodus pectoralis (perciformes, Osphronemidae), inferred from the mitochondrial DNA CO1 gene. Mitochondrial DNA Part B: Resources 4(2): 2966-2969.

Tan MP, Gan HM, Nabilsyafiq MH, Mazaln AG, Mat Jaafar TNA, Siti Azizah MN, DanishDaniel M, Sung YY. 2020. Genetic diversity of the Pearse's mudskipper Periophthalmus novemradiatus (Perciformes: Gobiidae) and characterization of its complete mitochondrial genome. Thalassas: An International Journal of Marine Sciences 36: 103-113.

Tan MP, Jamsari AFJ, Siti Azizah MN. 2012. Phylogeographic pattern of the stripe snakehead, Channa striata in Sundaland: ancient river connectivity, geographical and anthropogenic signatures. PLOS ONE 7(12): 1-11. DOI:10.1371/annotation/2be4a0a9-b3ed-492f-8c4d$15 \mathrm{~d} 3 \mathrm{a} 5 \mathrm{ae} 6 \mathrm{cab}$

Toro MA, Barragan C, Ovilo C. 2003. Estimation of genetic variability of the founder population in a conservation scheme using microsatellite. Animal genetics 34: 226-228 
732 Tzeng TD. 2007. Population structure and historical demography of the spotted mackerel 733 (Scomber australasicus) off Taiwan inferred from mitochondrial control region sequencing. Zoological studies 46(6): 656-663.

735 Viñas J, Tudela S. 2009. A validated methodology for genetic identification of tuna species

736

737

738

739

740

741

742

743

744

745

746

747 (Genus Thunnus). PloS one 4(10): 1-10. DOI10.1371/journal.pone.0007606.

Willette DA, Santos MD, Leadbitter D. 2016. Longtail tuna Thunnus tonggol (Bleeker, 1851) shows genetic partitioning across, but not within, basins of the Indo Pacific based on mitochondrial DNA. Journal of Applied Ichthyology 32: 318-323. DOI 10.1111/jai.12991

Wright S. 1931. Evolution in Mendelian populations. Genetics 16(2): 97-159 PMID: 17246615.

Yohannan TM, Abdurrahiman UC. 1998. Mackerel fishery of the Malabar area - major broods and their recruitment. Indian Journal of Fisheries 45(3): 249-256

Yu JN, Azuma N, Yoon M, Brykov V, Urawa S, Nagata M, Jin DH, Abe S. 2010. Population genetic structure and phylogeography of masu salmon (Oncorhynchus masou masou) inferred from mitochondrial and microsatellite DNA analyses. Zoological Science. 27(5): 375-385. DOI:10.2108/zsj.27.375. 


\section{Table $\mathbf{1}$ (on next page)}

Sampling locations, coordinates and collection date of 11 Thunnus tonggol populations from the surrounding seas (in the Indo Pacific region) of Malaysia. 
1 Table 1 Sampling locations, coordinates and collection date of 11 Thunnus tonggol populations from the surrounding

2 seas (in the Indo Pacific region) of Malaysia.

\begin{tabular}{cclccc}
\hline Region & No & \multicolumn{1}{c}{ Population } & Latitude (North) & Longitude (East) & Sampling date \\
\hline Strait of Malacca (SOM) & 1 & Kuala Perlis (KP), Perlis & $6^{\circ} 23^{\prime} 55.4^{\prime \prime} \mathrm{N}$ & $100^{\circ} 07^{\prime} 43.4^{\prime \prime} \mathrm{E}$ & $19 / 07 / 2017$ \\
& 2 & Pantai Remis (PR), Perak & $4^{\circ} 31^{\prime} 42.0^{\prime \prime} \mathrm{N}$ & $100^{\circ} 38^{\prime} 39.0^{\prime \prime} \mathrm{E}$ & $17 / 05 / 2018$ \\
& 3 & Sungai Besar (SB), Selangor & $3^{\circ} 39^{\prime} 50.4^{\prime \prime} \mathrm{N}$ & $100^{\circ} 59^{\prime} 16.6^{\prime \prime} \mathrm{E}$ & $15 / 05 / 2018$ \\
South China Sea 1 (SCS -1) & 4 & Pulau Kambing (TG), Terengganu & $5^{\circ} 19^{\prime} 19.7^{\prime \prime} \mathrm{N}$ & $103^{\circ} 07^{\prime} 42.3^{\prime \prime} \mathrm{E}$ & $02 / 10 / 2017$ \\
& 5 & Kuantan (KT), Pahang & $3^{\circ} 47^{\prime} 14.9^{\prime \prime} \mathrm{N}$ & $103^{\circ} 19^{\prime} 04.7^{\prime \prime} \mathrm{E}$ & $19 / 07 / 2017$ \\
& 6 & Tok Bali (TB), Kelantan & $5^{\circ} 52^{\prime} 35.5^{\prime \prime} \mathrm{N}$ & $102^{\circ} 27^{\prime} 29.9^{\prime \prime} \mathrm{E}$ & $10 / 07 / 2017$ \\
South China Sea 2 (SCS -2) & 7 & Kuching (KC), Sarawak & $1^{\circ} 33^{\prime} 27.0^{\prime \prime} \mathrm{N}$ & $110^{\circ} 21^{\prime} 38.7^{\prime \prime} \mathrm{E}$ & $10 / 03 / 2018$ \\
& 8 & Bintulu (BT), Sarawak & $3^{\circ} 10^{\prime} 13.8^{\prime \prime} \mathrm{N}$ & $113^{\circ} 02^{\prime} 25.8^{\prime \prime} \mathrm{E}$ & $08 / 03 / 2018$ \\
& 9 & Miri (MR), Sarawak & $4^{\circ} 233^{\prime} 31.1^{\prime \prime} \mathrm{N}$ & $113^{\circ} 59^{\prime} 07.6^{\prime \prime} \mathrm{E}$ & $07 / 03 / 2018$ \\
& 10 & Kota Kinabalu (KK), Sabah & $5^{\circ} 58^{\prime} 59.4^{\prime \prime} \mathrm{N}$ & $116^{\circ} 04^{\prime} 22.5^{\prime \prime} \mathrm{E}$ & $19 / 07 / 2017$ \\
Celebes Sea (CS) & 11 & Semporna (SM), Sabah & $4^{\circ} 28^{\prime} 49.8^{\prime \prime} \mathrm{N}$ & $118^{\circ} 36^{\prime} 39.7^{\prime \prime} \mathrm{E}$ & $20 / 03 / 2018$ \\
\hline
\end{tabular}

3 


\section{Table 2 (on next page)}

Molecular diversity, neutrality test, mismatch distribution and goodness of fit tests for Thunnus tonggol populations based on D-loop and ND5 sequences

*Significant at $\mathrm{P}<0.05$.

$\mathrm{N}$ : number of individuals; h: number of haplotype; S: number of segregating sites; $\mathrm{H}$ : haplotypes diversity; $\pi$ : nucleotide diversity; $\Theta_{0} / \Theta_{1}$ : before/after expansion; $\tau$ : relative time since population expansion; SSD: Sum of squared deviations; Hri: Harpending's raggedness index $\mathrm{KP}=$ Kuala Perlis; $\mathrm{PR}=$ Pantai Remis; $\mathrm{SB}=\mathrm{Sungai}$ Besar; $\mathrm{PK}=$ Pulau Kambing; $\mathrm{KT}=$ Kuantan; $\mathrm{TB}=$ Tok Bali; $\mathrm{KC}=$ Kuching; $\mathrm{BT}=$ Bintulu; $\mathrm{MR}=$ Miri; $\mathrm{KK}=$ Kota Kinabalu; SM=Semporna 
Table 2 Molecular diversity, neutrality test, mismatch distribution and goodness of fit tests for Thunnus tonggol populations

2 based on D-loop and ND5 sequences

\begin{tabular}{|c|c|c|c|c|c|c|c|c|c|c|c|}
\hline \multirow{2}{*}{ Population } & \multicolumn{4}{|c|}{ Genetic Diversity } & \multicolumn{2}{|c|}{ Neutrality test } & \multicolumn{3}{|c|}{ Mismatch distribution } & \multicolumn{2}{|c|}{ Goodness of fit tests } \\
\hline & $\mathbf{N}$ & $\mathbf{h}(\mathbf{S})$ & $\mathbf{H}$ & $\pi$ & Tajima's D & Fu's $F_{\mathrm{S}}$ & $\boldsymbol{\theta}_{0}$ & $\theta_{1}$ & $\tau$ & SSD & Hri \\
\hline \multicolumn{12}{|l|}{ D-loop } \\
\hline $\mathrm{KP}$ & 20 & $18(20)$ & 0.990 & 0.0239 & -0.99 & $-7.32 *$ & 0 & 99999.000 & 10.223 & 0.0072 & 0.0149 \\
\hline PR & 21 & $20(46)$ & 0.995 & 0.0238 & -0.95 & $-10.66^{*}$ & 0.016 & 93.860 & 9.291 & 0.0012 & 0.0069 \\
\hline SB & 18 & $18(45)$ & 1.000 & 0.0250 & -0.89 & $-10.13^{*}$ & 1.248 & 348.750 & 10.313 & 0.0034 & 0.0123 \\
\hline TG & 16 & $16(33)$ & 1.000 & 0.0200 & -0.74 & $-9.66^{*}$ & 0.002 & 99999.000 & 8.705 & 0.0093 & 0.0211 \\
\hline KT & 12 & $12(27)$ & 1.000 & 0.0195 & -0.49 & $-5.88^{*}$ & 0.000 & 99999.000 & 8.840 & 0.0114 & 0.0326 \\
\hline $\mathrm{TB}$ & 19 & $19(43)$ & 1.000 & 0.0245 & -0.76 & $-11.34 *$ & 0.000 & 99999.000 & 10.440 & 0.0093 & 0.0322 \\
\hline $\mathrm{KC}$ & 14 & $14(37)$ & 1.000 & 0.0238 & -0.70 & $-6.70^{*}$ & 0.000 & 3235.000 & 9.315 & 0.0107 & 0.0258 \\
\hline BT & 18 & $17(36)$ & 0.994 & 0.0203 & -0.83 & $-8.76^{*}$ & 0.000 & 58.750 & 9.113 & 0.0125 & 0.0212 \\
\hline MR & 19 & 19(44) & 1.000 & 0.0236 & -0.95 & $-11.64 *$ & 0.000 & 99999.000 & 9.955 & 0.0048 & 0.0142 \\
\hline KK & 22 & $21(52)$ & 0.996 & 0.0238 & -1.25 & $-11.68^{*}$ & 0.000 & 99999.000 & 9.871 & 0.0096 & 0.0164 \\
\hline SM & 24 & $23(43)$ & 0.996 & 0.0216 & -0.89 & $-14.95^{*}$ & 0.005 & 337.656 & 10.424 & 0.0032 & 0.0128 \\
\hline Overall & 203 & $180(105)$ & - & - & - & - & - & - & 8.514 & - & - \\
\hline Mean & 18 & - & 0.997 & 0.0227 & -0.86 & -9.88 & 0.116 & 54915.300 & 9.681 & 0.0075 & 0.0191 \\
\hline \multicolumn{12}{|l|}{ ND5 } \\
\hline $\mathrm{KP}$ & 20 & $13(14)$ & 0.937 & 0.0022 & $-1.88^{*}$ & $-10.03 *$ & 0.000 & 99999.000 & 2.039 & 2.0390 & 0.0295 \\
\hline PR & 19 & $14(22)$ & 0.965 & 0.0039 & $-1.85^{*}$ & $-8.34 *$ & 0.000 & 99999.000 & 3.439 & 3.4394 & 0.0023 \\
\hline SB & 21 & $11(14)$ & 0.868 & 0.0022 & $-1.78 *$ & $-5.87 *$ & 0.000 & 99999.000 & 1.933 & 1.9335 & 0.0012 \\
\hline TG & 16 & $10(14)$ & 0.917 & 0.0030 & -1.52 & $-4.49 *$ & 0.000 & 99999.000 & 1.439 & 1.4395 & 0.0465 \\
\hline $\mathrm{KT}$ & 13 & $10(10)$ & 0.923 & 0.0021 & $-1.80^{*}$ & $-7.93 *$ & 0.000 & 99999.000 & 1.947 & 1.9473 & 0.0197 \\
\hline TB & 19 & $9(9)$ & 0.848 & 0.0017 & -1.48 & $-4.85^{*}$ & 0.000 & 99999.000 & 1.535 & 1.5352 & 0.0148 \\
\hline $\mathrm{KC}$ & 18 & $11(14)$ & 0.909 & 0.0028 & $-1.55^{*}$ & $-5.66^{*}$ & 0.000 & 15.340 & 2.748 & 2.7481 & 0.0304 \\
\hline BT & 18 & $12(15)$ & 0.941 & 0.0031 & $-1.34 *$ & $-6.34 *$ & 0.000 & 99999.000 & 3.119 & 3.1191 & 0.0065 \\
\hline MR & 20 & $12(18)$ & 0.905 & 0.0030 & $-1.84 *$ & $-6.08^{*}$ & 1.130 & 216.470 & 1.650 & 1.6504 & 0.0009 \\
\hline KK & 21 & $12(15)$ & 0.929 & 0.0026 & $-1.71 *$ & $-6.74 *$ & 0.000 & 99999.000 & 2.281 & 2.2813 & 0.0099 \\
\hline
\end{tabular}




\begin{tabular}{lccccccccccc}
$\mathrm{SM}$ & 23 & $12(15)$ & 0.905 & 0.0027 & $-1.63^{*}$ & $-7.15^{*}$ & 0.000 & 99999.000 & 2.488 & 2.4883 & 0.0023 \\
\hline Overall & $\mathbf{2 0 8}$ & $\mathbf{6 0}(\mathbf{6 0})$ & - & - & - & - & - & - & $\mathbf{2 . 3 2 1}$ & - & - \\
\hline Mean & $\mathbf{1 9}$ & - & $\mathbf{0 . 9 1 6}$ & $\mathbf{0 . 0 0 2 7}$ & $\mathbf{- 1 . 6 7 *}$ & $\mathbf{- 6 . 6 8 *}$ & $\mathbf{0 . 1 0 3}$ & $\mathbf{8 1 8 3 8 . 4 0 0}$ & $\mathbf{2 . 2 3 8}$ & $\mathbf{0 . 0 1 4 9}$ & $\mathbf{0 . 0 7 4 9}$
\end{tabular}

* Significant at $\mathrm{P}<0.05$.

$4 \mathrm{~N}$ : number of individuals; h: number of haplotype; S: number of segregating sites; $\mathrm{H}$ : haplotypes diversity; $\pi$ : nucleotide diversity; $5 \Theta_{0} / \Theta_{1}$ : before/after expansion; $\tau$ : relative time since population expansion; SSD: sum of squared deviations; Hri: Harpending's raggedness index

$7 \mathrm{KP}=$ Kuala Perlis; $\mathrm{PR}=$ Pantai Remis; $\mathrm{SB}=$ Sungai Besar; $\mathrm{PK}=$ Pulau Kambing; KT=Kuantan; TB=Tok Bali; KC=Kuching; $\mathrm{BT}=\mathrm{Bintulu}$; $8 \mathrm{MR}=$ Miri; $\mathrm{KK}=$ Kota Kinabalu; $\mathrm{SM}=$ Semporna 


\section{Table 3 (on next page)}

Pairwise $\Phi_{\text {ST }}$ estimates (below diagonal) and genetic distance (upper diagonal) between sampling sites of Thunnus tonggol inferred by mtDNA D-loop region.

SOM (Strait of Malacca): KP=Kuala Perlis, PR=Pantai Remis, SB=Sungai Besar; SCS-1 (South China Sea 1): TG=Pulau Kambing, KT=Kuantan, TB=Tok Bali; SCS-2 (South China Sea 2): $\mathrm{KC}=$ Kuching, $\mathrm{BT}=$ Bintulu, MR=Miri, KK=Kota Kinabalu; CS (Celebes Sea): SM=Semporna; ECIO (east coast of Indian Ocean); WCIO (west coast of India Ocean); TW=Taiwan. Bold numbers indicate statistically significant after FDR correction at $\alpha=0.05$. 
1 Table 3 Pairwise $\Phi_{\mathrm{ST}}$ estimates (below diagonal) and genetic distance (upper diagonal) between sampling sites of Thunnus tonggol

2 inferred by mtDNA D-loop region.

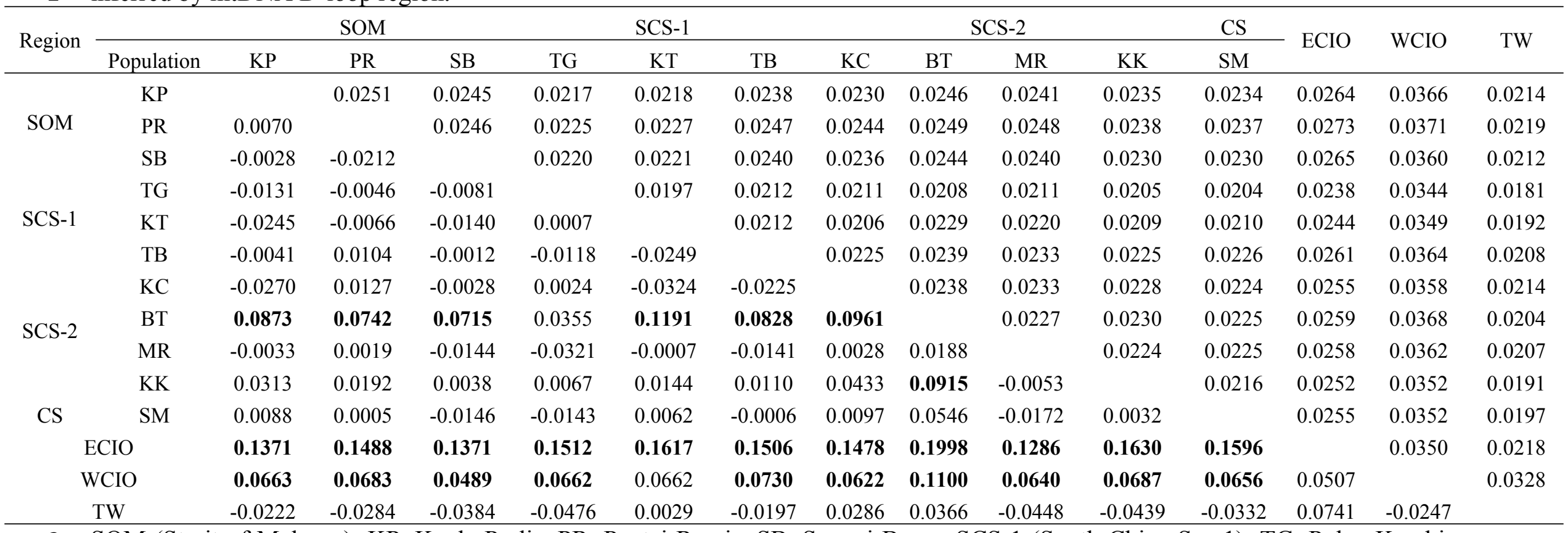

3 SOM (Strait of Malacca): KP=Kuala Perlis, PR=Pantai Remis, SB=Sungai Besar; SCS-1 (South China Sea 1): TG=Pulau Kambing,

$4 \mathrm{KT}=$ Kuantan, TB=Tok Bali; SCS-2 (South China Sea 2): KC=Kuching, BT=Bintulu, MR=Miri, KK=Kota Kinabalu; CS (Celebes Sea):

$5 \mathrm{SM}=$ Semporna; ECIO (east coast of Indian Ocean); WCIO (west coast of India Ocean); TW=Taiwan.

6 Bold numbers indicate statistically ignificant after FDR correction at $\alpha=0.05$. 


\section{Table 4 (on next page)}

Pairwise $\Phi_{\text {ST }}$ estimates (below diagonal) and genetic distance (upper diagonal) between sampling sites of Thunnus tonggol inferred by mtDNA ND5 gene.

SOM (Strait of Malacca): KP=Kuala Perlis, PR=Pantai Remis, SB=Sungai Besar; SCS-1 (South

China Sea 1): TG=Pulau Kambing, KT=Kuantan, TB=Tok Bali; SCS-2 (South China Sea 2):

$\mathrm{KC}=$ Kuching, $\mathrm{BT}=$ Bintulu, MR=Miri, KK=Kota Kinabalu; CS (Celebes Sea): SM=Semporna

Bold number indicates statistically significant after FDR correction at $\alpha=0.05$. 
Table 4 Pairwise $\Phi_{\mathrm{ST}}$ estimates (below diagonal) and genetic distance (upper diagonal) between sampling sites of Thunnus tonggol inferred by mtDNA ND5 gene.

\begin{tabular}{cccccccccccccc}
\hline \multirow{2}{*}{ Region } & \multirow{2}{*}{ Population } & \multicolumn{3}{c}{ SOM } & \multicolumn{3}{c}{ SCS-1 } & \multicolumn{4}{c}{ SCS-2 } \\
\cline { 3 - 12 } & & KP & PR & SB & TG & KT & TB & KC & BT & MR & KK & SM \\
\hline \multirow{3}{*}{ SOM } & KP & & 0.0030 & 0.0023 & 0.0026 & 0.0021 & 0.0020 & 0.0025 & 0.0029 & 0.0026 & 0.0024 & 0.0025 \\
& PR & -0.0075 & & 0.0031 & 0.0035 & 0.0030 & 0.0028 & 0.0033 & 0.0038 & 0.0035 & 0.0032 & 0.0033 \\
& SB & -0.0089 & -0.0090 & & 0.0027 & 0.0022 & 0.0020 & 0.0026 & 0.0030 & 0.0027 & 0.0024 & 0.0025 \\
& TG & 0.0082 & 0.0207 & 0.0283 & & 0.0025 & 0.0024 & 0.0029 & 0.0031 & 0.0030 & 0.0028 & 0.0028 \\
SCS-1 & KT & -0.0171 & 0.0046 & -0.0031 & -0.0055 & & 0.0019 & 0.0024 & 0.0029 & 0.0026 & 0.0023 & 0.0024 \\
& TB & -0.0037 & 0.0090 & -0.0106 & 0.0076 & -0.0150 & & 0.0023 & 0.0027 & 0.0024 & 0.0022 & 0.0022 \\
& KC & 0.0058 & -0.0069 & -0.0074 & 0.0006 & -0.0079 & -0.0050 & & 0.0032 & 0.0029 & 0.0027 & 0.0027 \\
& BT & 0.0425 & 0.0436 & $\mathbf{0 . 0 7 3 9}$ & -0.0077 & 0.0550 & 0.0460 & 0.0444 & & 0.0032 & 0.0031 & 0.0031 \\
SCS-2 & MR & -0.0077 & -0.0011 & 0.0015 & -0.0169 & -0.0064 & -0.0095 & -0.0200 & -0.0015 & & 0.0028 & 0.0028 \\
& KK & -0.0169 & -0.0030 & -0.0095 & 0.0133 & -0.0203 & -0.0067 & 0.0032 & 0.0539 & -0.0023 & & 0.0026 \\
& SM & -0.0064 & 0.0028 & -0.0009 & -0.0144 & -0.0213 & -0.0090 & -0.0254 & 0.0235 & -0.0242 & -0.0106 & \\
\hline
\end{tabular}

3 SOM (Strait of Malacca): KP=Kuala Perlis, PR=Pantai Remis, SB=Sungai Besar; SCS-1 (South China Sea 1): TG=Pulau Kambing,

$4 \mathrm{KT}=$ Kuantan, TB=Tok Bali; SCS-2 (South China Sea 2): KC=Kuching, BT=Bintulu, MR=Miri, KK=Kota Kinabalu; CS (Celebes Sea):

$5 \mathrm{SM}=$ Semporna

6 Bold number indicates statistically significant after FDR correction at $\alpha=0.05$. 


\section{Figure 1}

Sampling locations of Thunnus tonggol along the Malaysian coastal waters A) and additional samples (B).

$\mathrm{KP}=$ Kuala Perlis; $\mathrm{PR}=$ Pantai Remis; $\mathrm{SB}=$ Sungai Besar; $\mathrm{TG}=$ Pulau Kambing; $\mathrm{KT}=$ Kuantan;

$\mathrm{TB}=$ Tok Bali; KC=Kuching, $\mathrm{BT}=$ Bintulu; MR=Miri; KK=Kota Kinabalu; SM=Semporna;

$T W=$ Taiwan; $K H=K o c h i ; V R=V e r a v a l ; R N=R a t n a g i r i ; A D=A n d a m a n$ Sea. Exact coordinates of additional samples are unknown. 


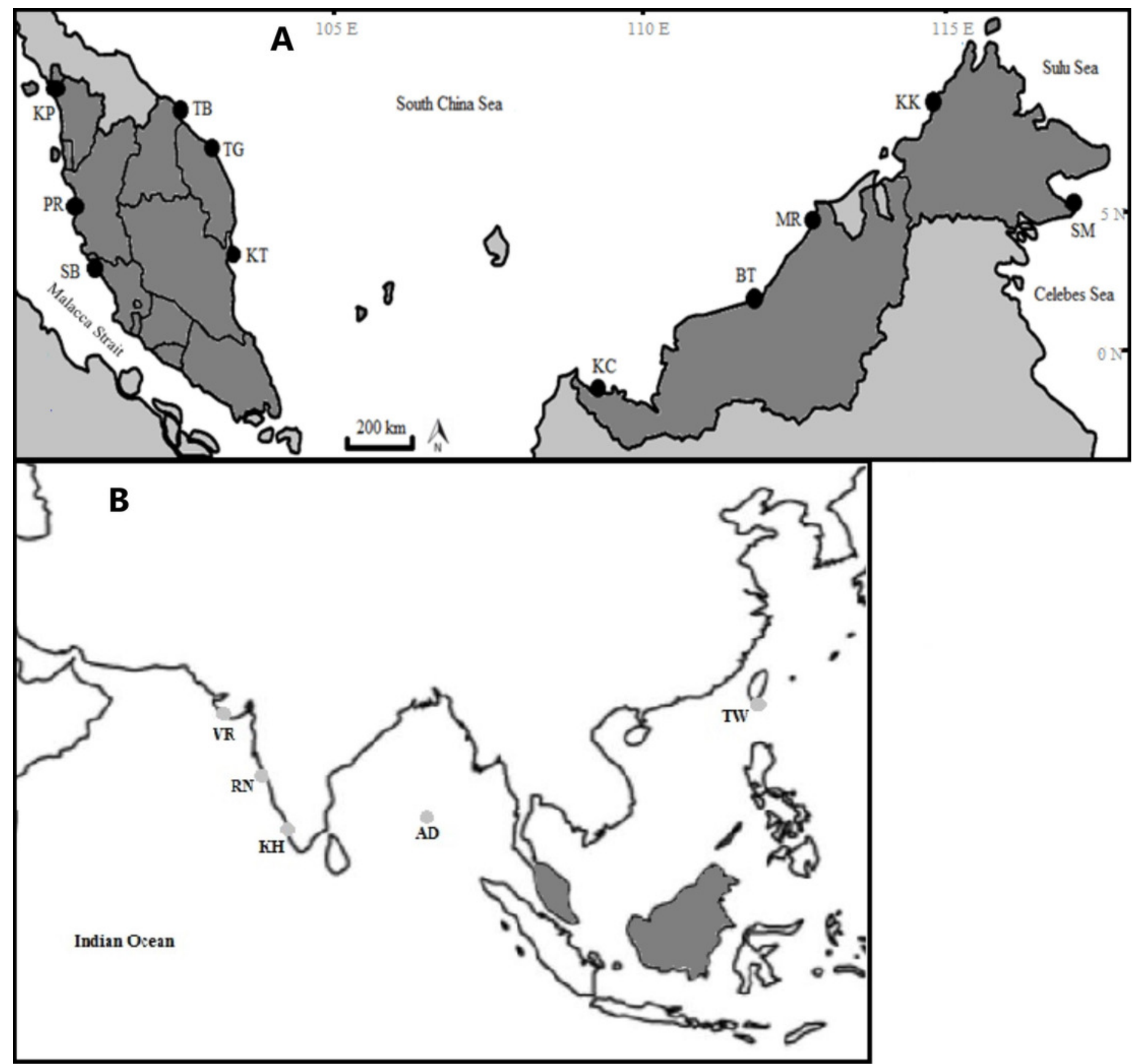


Figure 2

Maximun likelihood ( $M L)$ gene trees show the relationship of Thunnus tonggol haplotypes inferred from (A) D-loop marker (tree was compressed for a better illusration) (B) ND5 gene.

Branches were drawn to scale and bootstrap values $<50 \%$ were not shown. (The original D-loop ML tree was presented in Supplementary 1). All regions = SCS-1, SCS-2, SOM, CS, WCIO, ECIO, TW; WCIO = west coast Indian Ocean
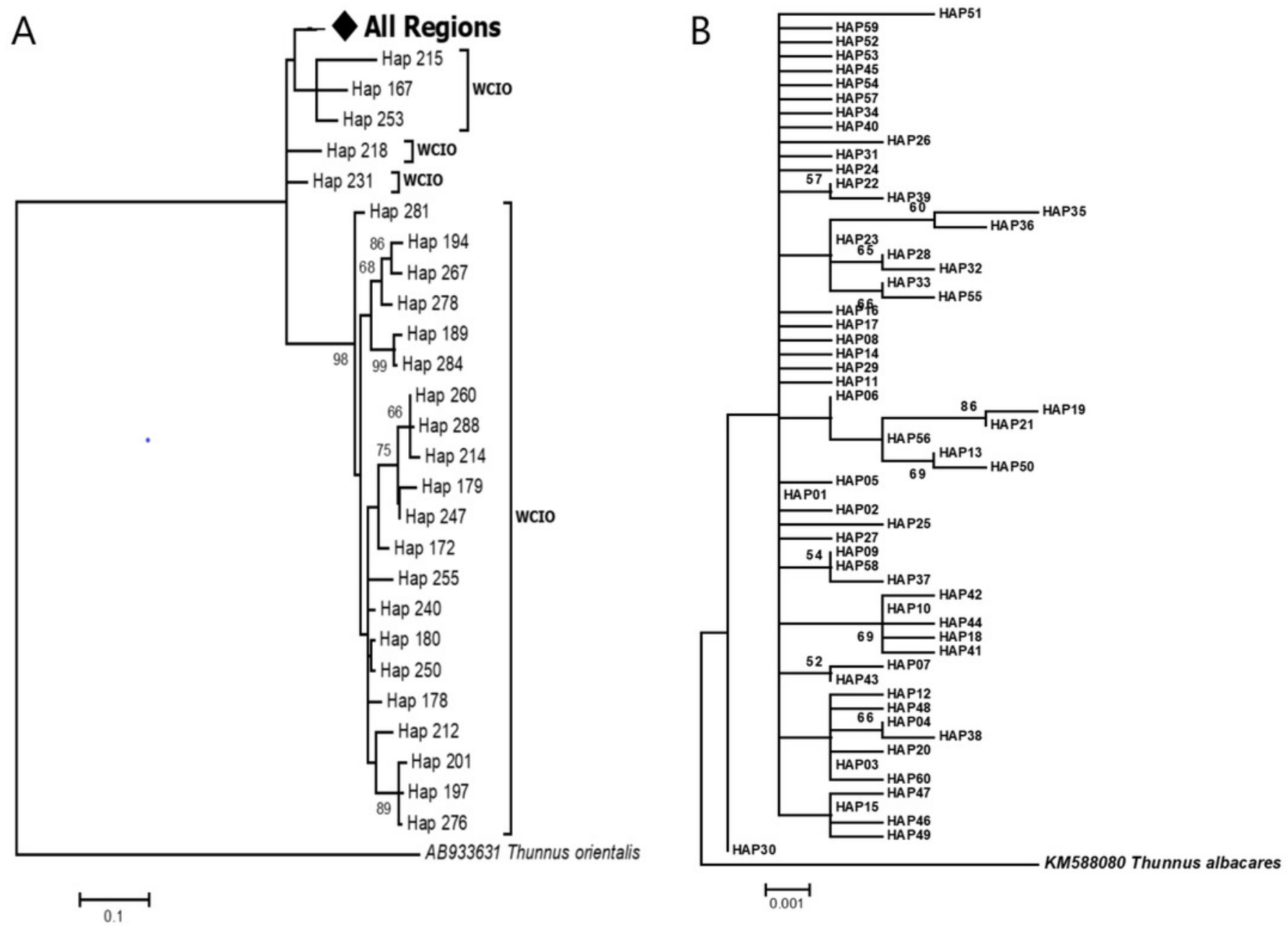


\section{Figure 3}

Haplotypes network diagram inferred from D-loop region.

Node size corresponds to the haplotype frequencies; minimum node size is one individual. Black dot represents median vector. Dash line represents nucleotide mutation. Populations: $\mathrm{KP}=\mathrm{Kuala}$ Perlis; $\mathrm{PR}=$ Pantai Remis; $\mathrm{SB}=$ Sungai Besar; TG=Pulau Kambing; $\mathrm{KT}=$ Kuantan; $\mathrm{TB}=$ Tok Bali; $\mathrm{KC}=$ Kuching; $\mathrm{BT}=$ Bintulu; $\mathrm{MR}=$ Miri; KK=Kota Kinabalu; SM=Semporna.

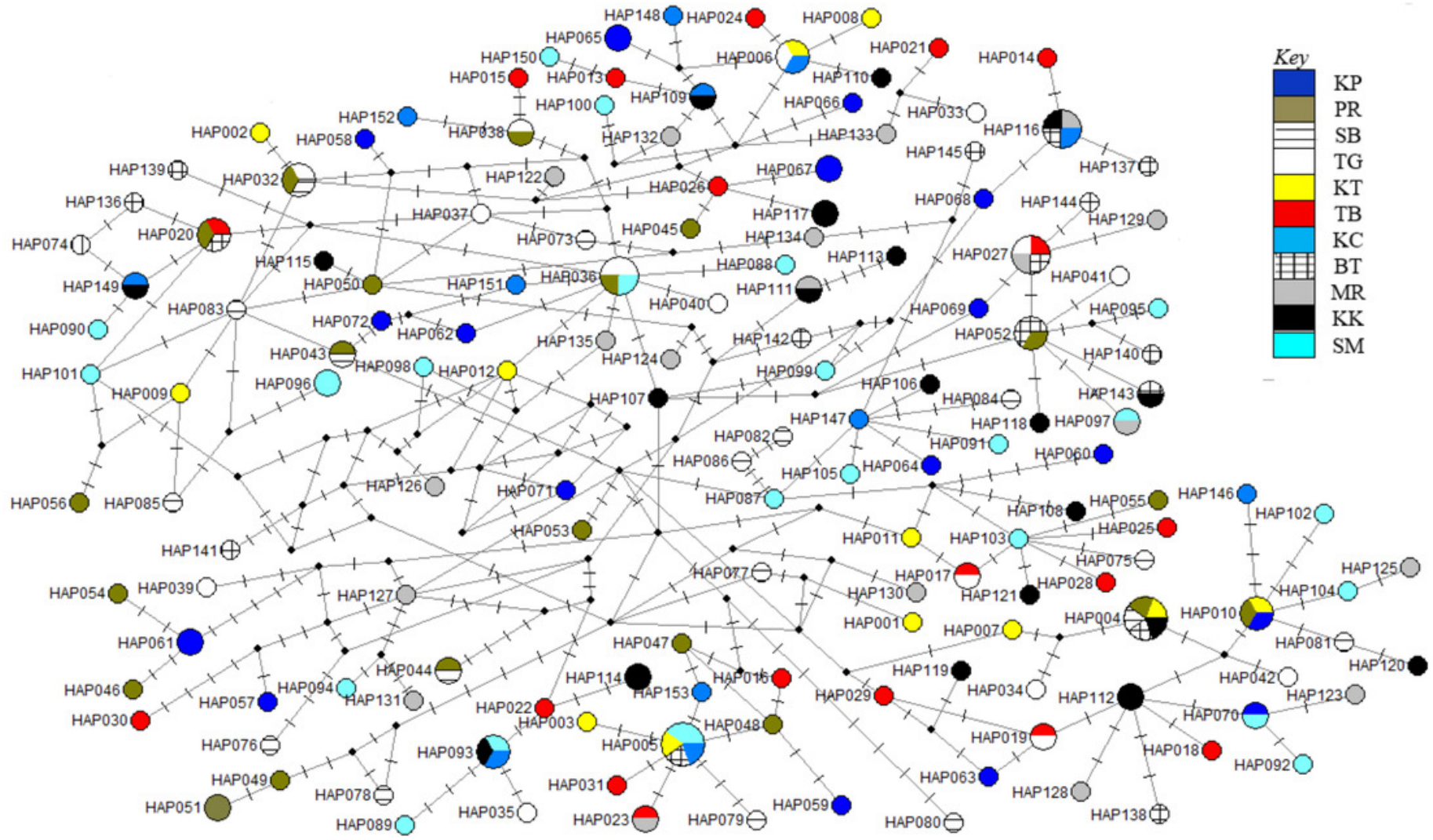


Figure 4

Haplotype network diagram inferred from the ND5 gene.

Node size corresponds to the haplotype frequencies; minimum node size is one individual. Black dot represents the median vector. Dashed line represents a nucleotide mutation.

Populations: KP=Kuala Perlis; PR=Pantai Remis; $\mathrm{SB}=$ Sungai Besar; $\mathrm{TG}=$ Pulau Kambing;

$\mathrm{KT}=$ Kuantan; $\mathrm{TB}=$ Tok Bali; KC=Kuching; $\mathrm{BT}=$ Bintulu; MR=Miri; KK=Kota Kinabalu;

SM=Semporna.

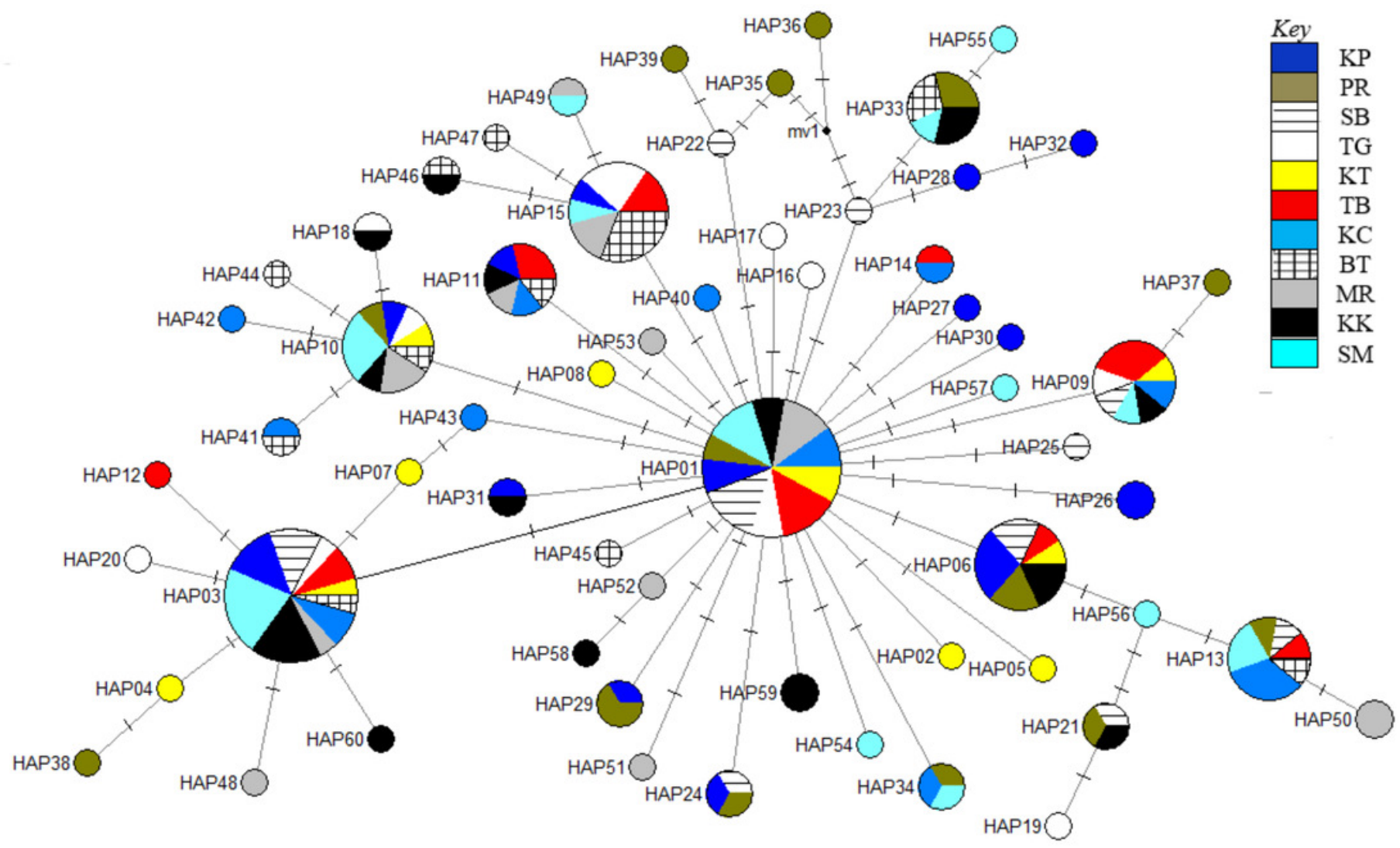




\section{Figure 5}

Bayesian Skyline Plots of the mtDNA (A) D-loop marker and (B) ND5 gene of Thunnus tonggol populations in Malaysia.

The $\mathrm{Y}$-axis indicates effective population size $(\mathrm{Ne}) \times$ generation time, while the $\mathrm{X}$-axis indicates mean time in thousands of years before present. The thick line represents the average and the blue band represents the standard error.
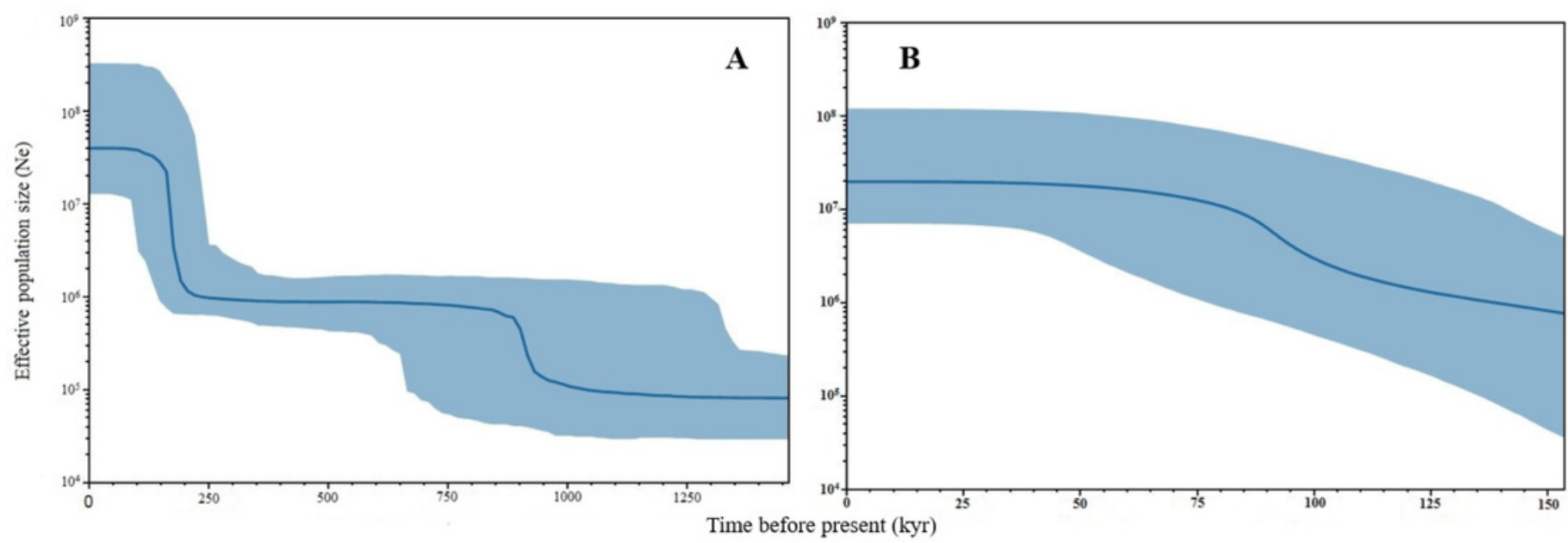
Figure 6

Mismatch distributions (pairwise number of differences) for the mtDNA (A) D-loop region (B) ND5 gene of Thunnus tonggol showing the expected and observed pairwise differences between sequences with the respective frequencies.
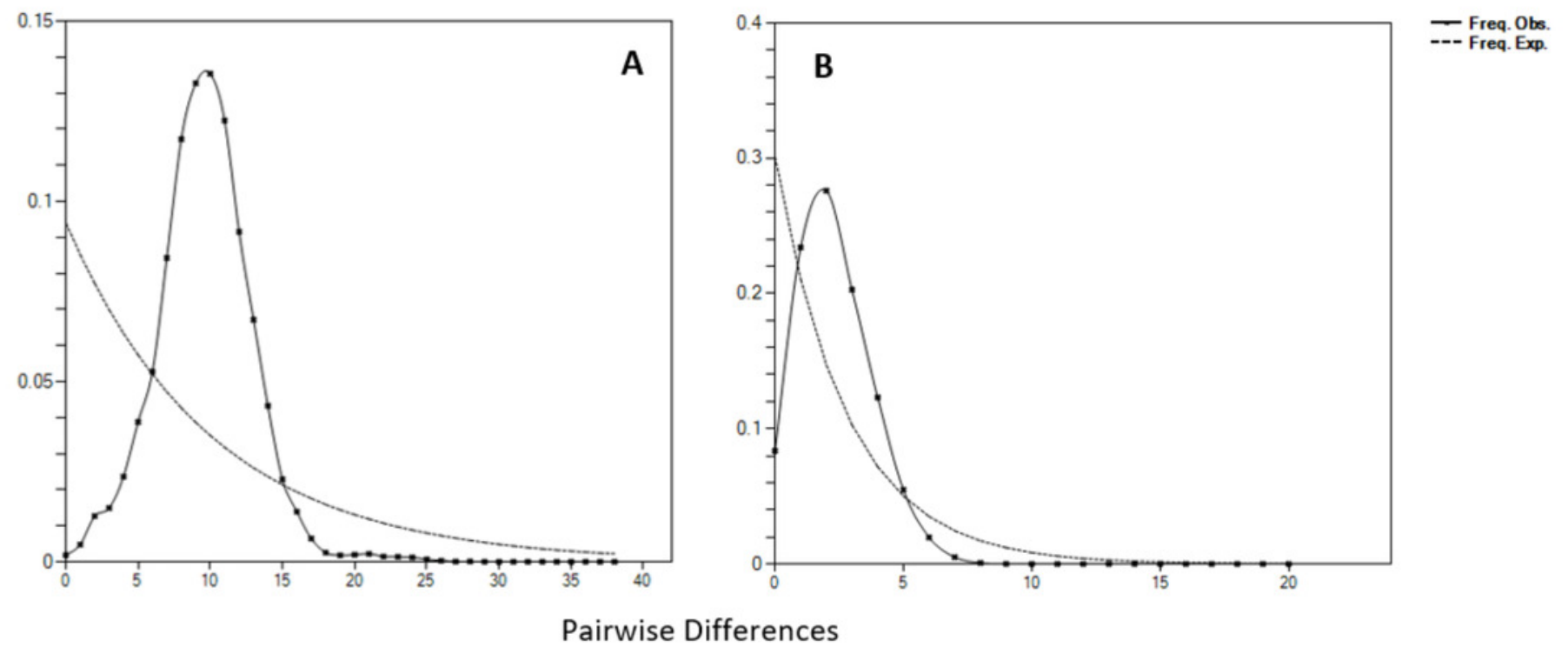